\title{
Examining the Success of the Online Public Grievance Redressal Systems: An Extension of the IS Success Model
}

\author{
Nripendra P. Rana \\ School of Management, Swansea University, UK \\ nrananp@gmail.com \\ Yogesh K. Dwivedi ${ }^{1}$ \\ School of Management, Swansea University, UK \\ ykdwivedi@gmail.com \\ Michael D. Williams \\ School of Management, Swansea University, UK \\ M.D.Williams@swansea.ac.uk \\ Banita Lal \\ Nottingham Business School, Nottingham Trent University, UK \\ banita.lal@ntu.ac.uk
}

\begin{abstract}
The purpose of this paper is to examine the success of the online public grievance redressal system (OPGRS) from the perspective of the citizens of India. The empirical outcomes provided the positive significant connections between all 13 hypothesized relationships among the seven constructs. The empirical evidence and discussion presented in the study can help the Indian government to improve upon and fully utilize the potential of the OPGRS for transparent and corruption free country.
\end{abstract}

Keywords: Online Public Grievance Redressal Systems (OPGRS), Systems Success, EGovernment, Trust, DeLone and McLean Model, India.

\section{$\underline{\text { Authors Bio }}$}

Nripendra P. Rana is a Lecturer at the School of Management, Swansea University in the UK. He holds BSc (Hons), MCA, MTech, and MPhil degrees from India. He obtained his MBA with distinction and $\mathrm{PhD}$ from Swansea University, UK. He has a diverse work experience of teaching in the area of computer engineering and applications at undergraduate and postgraduate levels. He also possesses a good experience in the field of software development.

Yogesh K. Dwivedi is a Professor of Digital and Social Media at the School of Management, Swansea University, Wales, UK. He obtained his $\mathrm{PhD}$ and MSc in Information Systems from Brunel University, UK. He has co-authored several papers which have appeared in international refereed journals such as CACM, DATABASE, EJIS, ISJ, ISF, JCIS, JIT, JORS, and IMDS. He is an Associate Editor of EJIS, Assistant Editor of TGPPP, Senior

\footnotetext{
${ }^{1}$ Corresponding Author: Yogesh K. Dwivedi, School of Management, Room 32, Haldane Building, Swansea University, Singleton Park, Swansea, SA2 8PP, Wales, UK. Tel: +44 (0) 1792 602340, Fax: +44 (0) 1792 295626, Email: ykdwivedi@gmail.com
} 
Editor of JECR and member of the editorial board/review board of several journals. He is a member of the AIS and IFIP WG8.6.

Michael D. Williams is a Professor in the School of Management at Swansea University in the UK. He holds a BSc from the CNAA, an MEd from the University of Cambridge, and a $\mathrm{PhD}$ from the University of Sheffield. He is a member of the British Computer Society and is registered as a Chartered Engineer. Prior to entering academia Professor Williams spent twelve years developing and implementing ICT systems in both public and private sectors in a variety of domains including finance, telecommunications, manufacturing, and local government, and since entering academia, has acted as consultant for both public and private organizations. He is the author of numerous fully refereed and invited papers within the ICT domain, has editorial board membership of a number of academic journals, and has obtained external research funding from sources including the European Union, the Nuffield Foundation, and the Welsh Assembly Government.

Banita Lal is a Lecturer in Nottingham Business School, Nottingham Trent University, UK. She obtained her PhD entitled 'Homeworkers' Usage of Mobile Phones across Work-Home Boundaries' and MSc in Information Systems from the School of Information Systems, Computing and Mathematics, Brunel University, UK.

\section{INTRODUCTION}

Starting from the early 1990s, the revolution of information and communication technologies (ICTs) has made major and brisk changes in the day-to-day life of people and governments (Floropoulos, Spathis, Halvatzis, \& Tsipouridou, 2010). Realizing this, many governments across the world are transforming into new forms of government called electronic government or e-government (Akman, Yazici, Mishra, \& Arifoglu, 2005) to reinforce and maintain their positions in the global competition (Sharifi \& Zarei, 2004). Though egovernment provides obvious benefits to governments themselves, professionals, and organizations, it is citizens who actually receive the broadest range of benefits (Jaeger, 2003; Rana, Dwivedi, \& Williams, 2013c). Looking at this aspect, one of the most significant requirements of citizen's day-to-day life such as their grievances against the government systems, officials, organizations, and bureaucratic structures in a country like India is quite evident.

As governments develop e-government systems to deliver services to the people (Wang \& Liao, 2008) and given the widespread influence of the Internet on the day-to-day activities of a large section of stakeholders, it has become significant than ever to understand what makes a system successful (Schaupp, Belanger, \& Fan, 2009). To date, research has focused primarily on validating existing models through assessment of generic information systems entrenched within organizational settings (Rai, Lang, \& Welker, 2002; Schaupp et al., 2009; Seddon \& Kiew, 1994; Seddon \& Kiew, 1996) to examine effectiveness or user satisfaction with the system. However, Rai et al. (2002) suggested for more thorough testing of success models precisely in evolving and volitional (where the use of the system in completely 
voluntary) IS contexts. Online public grievance redressal system is one such specific egovernment system, which is emerging slowly and steadily in the country like India and whose use is completely voluntary in nature. This system is largely meant for addressing the grievances, issues, and problems of citizen's everyday life and gets them resolved online by the high-level government officials designated for it. It provides a huge benefit to the people and eventually the society by solving their problems without much hassle.

Grievance redress mechanism is a part and parcel of the machinery of any administration. No administration can claim to be answerable, responsive, and user-friendly unless it has established a proficient and effectual grievance redress mechanism. In fact, the grievance redress mechanism of an organization is an approximation to scrutinize its efficiency and effectiveness as it provides significant feedback on the working of its administration. The grievances from public are accepted at various points in the Government of India. There are mainly two designated agencies in the central government handling these grievances namely Department of Administrative Reforms and Public Grievances, Ministry of Personnel, Public Grievances and Pensions, and Directorate of Public Grievances, Cabinet Secretariat. The public grievance redress mechanism functions in India on a decentralized basis. An officer of the level of Joint Secretary is designated as Director of Grievances of the Ministry/Department/Organization.

The major reasons of grievances are mainly due to the socio-economic reasons such as prevalent corruption in the ministries, government organizations, and bureaucratic systems, which are ubiquitous in the current society. The people feel themselves helpless against corruptions and are likely to tolerate it in their day-to-day lives. But, the factors such as lack of awareness and lack of relevant information make this process even more tedious. Looking at this aspect, the online public grievance redressal system has been designed and developed to take care of all such problems of the people without stepping in to the offices of ministries and government organizations. In majority of the cases, citizens don't even know who is accountable to listen to their problems. Therefore, the significance of such e-government systems is felt even more for smooth, transparent and impartial running of the governments. Thus, the OPGRS has emerged as such e-government system, which is primarily meant for addressing the grievances, issues, and problems of citizen's everyday life and gets them resolved online by the high-level government officials designated for it (Rana, Dwivedi, \& Williams, 2013b).The success of this system can be measured only when a large section of the society adopts this system to register complaints and the government responses properly to their issues leading to the citizens' satisfaction.

Due to the facts mentioned above, it is quite logical to examine the success of the OPGRS by analysing the views of the citizens of India. Hence, the aim of this study is to identify the success factors from the potential users of the OPGRS by employing IS success model in answering two research questions: (1) What influences the OPGRS success factors? (2) To what level such factors influence the success of the system? Finding the answers can instigate advancement and improve the performance of services provided through this system by the concerned government departments and agencies. This study attempts to measure the OPGRS success factors to the interrelationship between the IS success model, perceived trust, 
subjective norms, and attitude toward using the system. Including additional constructs such as subjective norms, and perceived trust on the IS success model (DeLone \& McLean, 1992) is a contribution to the research as these constructs are significant in examining the success of the system. In addition, intention itself represents an individual's attitude toward the behaviour (Lin, Fofanah, \& Liang, 2011), we considered that the key predictors of system's success (i.e., information quality and system quality) could determine potential user's attitude toward behavioral intention. Ajzen \& Fishbein (1972) also argued that attitude and subjective norms were the significant factors on the behavioral intention formation. Moreover, it has been argued that users with a more positive attitude toward using the system were likely to be more satisfied with the system (Ajzen \& Fishbein, 1980; Heeks, 2006; Shin, 2007; Lin et al., 2011) and eventually intended to use it (Lin et al., 2011).

\section{LITERATURE REVIEW}

As far as e-government adoption research is concerned, a few studies (e.g., Chai, Herath, Park, \& Rao, 2006; Chen, 2010; Floropoulos et al., 2010; Gotoh, 2009; Hsu \& Chen, 2007; Hu, Brown, Thong, Chan, \& Tam, 2009; Sambasivan, Wemyss, \& Rose, 2010; Scott \& DeLone, 2009; Teo, Srivastava, \& Jiang, 2008) have used IS Success Models to measure the success of the different e-government systems. It has been argued that e-government approaches were analysed mainly from a supply-side perspective and not the demand-side aspects (Bargas-Avila, Brenzikofer, Roth, Tuch, Orsini, \& Opwis, 2010; Janssen, Rotthier, \& Snijkers, 2004; Reddick, 2005). As government develops the systems to offer such services to the citizens, assessment efforts are required to measure the efficiency, effectiveness and success of the concerned systems. Such evaluation efforts would allow government departments and agencies to determine whether they are capable to deliver what citizens require and provide expected services accordingly (Gupta \& Jana, 2003; Wang \& Liao, 2008).

From the analysis of the research findings of the various literature studies, Chai et al. (2006) implied that success of e-government depends on how governments offer high quality and user-oriented e-government services to the citizens. One of the major factors of the success of the e-government is government websites. The relationship between the quality of a website and its success was analysed in some research papers (Chai et al., 2006). Palmer (2002) discussed that quality of a website can be measured by its connection speed, navigability, interactivity, responsiveness, and quality substance. On the other hand, it was found that website quality is supposed to have positively linked toward developing trusting intention on e-commerce website (McKnight, Choudhury, \& Kacmar, 2000). Therefore, website service quality can be considered as one of the strong interpreters of e-government success and user's intention to constantly use an e-government website (Chai et al., 2006).

Hsu \& Chen (2007) provided an alternative conceptualization of the IS success model for examining the IS use behaviour of e-government in Taiwanese context. Their analysis indicated that user intention to use IS in e-government is governed by social (i.e. normative pressure) and functional value (i.e. information and service quality) rather than conditional value (i.e. system quality) and satisfaction. Teo et al. (2008) have analysed the influence of 
trust on the specific e-government systems on the quality constructs (i.e. information, system, and service quality) of the IS success model. They argued that higher level of citizen's trust would be positively associated with information, system, and service quality of the systems (Teo et al., 2008). Similarly, backed by the IS success model, Wang et al. (2010) devised a model for citizen's sustainable trust in e-government.

Gotoh (2009) undertook a similar analysis of the online tax declaration services for the Japanese government and examined it quantitatively to elucidate the factors that enhance user's satisfaction with such services. The paper used IS success model with two amendments where preparation quality and result quality were the constructs used apart from system quality, which was directly driven from the IS success model. Hu et al. (2009) examined the determinants of service quality and continuance intention on the eTax system in context of Hong Kong. The data analysis supported both service traits (i.e. security and convenience) and one technology trait (i.e. perceived ease of use) as the key determinants of the service quality. They also observed that perceived usefulness was not found as the strongest predictor of continuance intention but service quality was. Using the extension of IS success model, Schaupp et al. (2009) examined the success of websites beyond e-commerce. The authors contributed to the existing knowledge by examining the IS success model factors in a range of volitional website contexts. The research highlighted the fact the success of a website is context dependent.

Scott \& DeLone (2009) provided a multi-faceted framework for understanding the success of e-government websites from the citizen's perspectives. They established the role of net benefits in the evaluation of e-government success and extended the knowledge of egovernment success by determining the influence IT quality constructs. Chen (2010) discussed taxpayer's satisfaction with the online system for filing the individual income tax returns in context of Taiwan. The system under discussion covered its information, system, and service qualities, which are the precursors of the user's satisfaction with any system. By the use of DeLone and McLean's IS success model, the author intended to exhibit how the use of the system could be improved by the growing software satisfaction with it. The research also found that information and system quality were the significant factors toward achieving this goal (Chen, 2010).

Floropoulos et al. (2010) measured the success of the Greek taxation information systems (TAXIS) from the perspective of expert employees using the constructs comprising of information, system, and service quality, perceived usefulness, and user satisfaction and found the strong links between five success constructs. However, they found the effect of system quality on perceived usefulness quite low and on user satisfaction as non-significant. They argued that adequately computer and Internet literate sample might be the reason for this outcome as system quality may not be a critical factor for determining perceived usefulness and user's satisfaction in this scenario. Sambasivan et al. (2010) used an extended IS success model of DeLone \& McLean (2003) to examine the factors that influence the intention to use and actual use of the electronic procurement system by various ministries in the Malaysian government. They used DeLone \& McLean IS success model by extending it with the factors such as trust, facilitating conditions, and web-design quality and found them 
strongly linked with intention to use. Using the DeLone and McLean's model, Khayun et al. (2012) investigated the factors responsible for the success of e-Excise system in context of Thailand. Their results suggested that by enhancing trust in the e-government website, and perceptions of information, system, and service quality would enhance system usage and user satisfaction which would eventually influence perceived net benefits.

\section{THEORETICAL BACKGROUND - IS SUCCESS MODELS}

Researchers have developed various models to describe to what makes some IS 'successful'. It was argued that acceptance of an information system does not necessarily indicate its success; however it can be considered as a possible precursor for a success of the system (Petter, DeLone, \& McLean, 2008). There are mainly three theories given in the area of IS success. The first IS success model was given by DeLone \& McLean (1992) with six factors. There were many criticisms of this model by various researchers (including Pitt, Watson, \& Kavan, 1995; Seddon, 1997; Seddon \& Kiew, 1996) on some of its constructs such as individual and organizational impact and use. Seddon (1997) introduced a re-specified model of DeLone and McLean where use of the system was considered to have results of various types, perceived usefulness was introduced in the model as an IS measure. Responding to the criticisms by the researchers on their model, DeLone and McLean updated their prior model with introduction of both intention to use and use in place of use and net benefits in place of their previous constructs of individual and organizational impacts. The brief description of these three major IS success models is provided below.

\section{DeLone \& McLean's (1992, 2003) IS Success Models}

Prior efforts to define IS success were ill-defined due to the intricate, inter-dependent, and multi-faceted nature of IS success (Petter et al., 2008). To address this problem, DeLone \& McLean (1992) performed a review of the research published during 1981-1987 to develop a taxonomy of IS success. They showed that IS success was the association of six factors namely system quality, information quality, use, user's satisfaction, individual impact, and organizational impact (DeLone \& McLean, 1992). Soon after the publication of this model, IS researchers started proposing changes to it. Seddon \& Kiew (1996) reviewed a part of the IS success model (i.e. system quality, information quality, use, and user satisfaction) and customized the construct 'use'. They 'conjectured that the underlying success construct that the researchers have been trying to tap is Usefulness, not use' (Seddon \& Kiew, 1996, p. 93). Their idea of usefulness was equivalent to the construct called perceived usefulness from TAM (Petter et al., 2008) by Davis (1989). They argued that 'use' is a suitable measure for voluntary systems. However, as far as the mandatory systems use is concerned, usefulness happens to be a better measure of IS success than use (Seddon \& Kiew, 1996). However, latter DeLone \& McLean (2003) argued the considerable variability of 'use' even in mandatory systems and justified its retention.

Latter in the year 2003, DeLone \& McLean discussed many of the significant IS research efforts that have applied, validated, challenged, and offered enrichments to their original model. Realizing the proposed modifications to their model, the updated IS success model accepted the Pitt et al. (1995) recommendations to incorporate service quality as a construct. 
The other update to the model attended to the criticism that an IS can influence levels other than individual and organizational levels. Because IS success influences not only individuals and organizations but also workgroups, industries, and even societies (Myers, Kappelman, \& Prybutok, 1997; Seddon, Staples, Patnayakuni, \& Bowtell, 1999), DeLone \& McLean substituted the variables, individual and organizational impact, with net benefits with accounting for benefits at different levels of analysis and proposed an updated model which represents the relationship between system quality, information quality, service quality, use, user satisfaction, and net benefit. Thus, system quality, information quality, and service quality became the significant dimensions of the IS success model.

While IS success models have gained considerable attention among researchers, little research has been undertaken to examine the success of e-government systems (Rana, Dwivedi, \& Williams, 2013a). Hence, there is a need to measure whether the traditional IS success models can be broadened to examine e-government systems success (Wang \& Liao, 2008). A decisive improvement made to this model was about the further explanation of the use construct. The authors described the construct as: 'Use must precede user satisfaction in a process sense, but positive experience with use will lead to greater user satisfaction in a causal sense' (DeLone \& McLean, 2003). They further clarified that enhanced user satisfaction would direct to higher intention to use the system, which in turn can affect use of the system (DeLone \& McLean, 2003).

\section{RESEARCH MODEL DEVELOPMENT AND HYPOTHESES}

\section{Overview of Research Model}

Our theoretical development for examining the success of the OPGRS will follow up and emerge from the IS success models of DeLone \& McLean $(1992,2003)$ in volitional contexts. DeLone \& McLean $(1992,2003)$ are among few such theories and models that have helped researchers to establish some of the significant factors that have influenced the acceptance and use of e-government services (Dwivedi, Weerakkody, \& Janssen 2012). The decision for not considering certain constructs of these models to design and develop a proposed research model for this study is based on assured logical facts. At the outset, so far as the arguments for service quality is concerned it mainly measures the service quality of the IT departments as opposed to the specific IT applications. It mainly examines user's beliefs and their insight of IT department (Petter et al., 2008). Therefore, we are not going to consider service quality from our proposed research model as our intention is to measure the success of a particular information systems and not the IT department. Petter \& McLean (2009) reviewed 52 empirical studies that examined different relationships of IS success model at the individual level and found that only one study examined the relationship between service quality and intention to use and the meta-analytic results of service quality on the constructs namely use and user satisfaction were found non-significant. Hence, this analysis also supported and consolidated our consideration of not including service quality construct of the IS success model in our proposed research model.

As far as the construct 'use' is concerned, we do not intend to consider in our model due to the fact that the respondents to whom data have been collected are the potential adopters of 
the systems. They were rather shown the working of the system and its benefits and are expected to use this system in the future. Therefore, measuring their use behaviour is beyond the scope of this paper. Seddon \& Kiew (1996) and Seddon (1997) argued that 'use' can be opted as a system success measure only if a system is used, leading to the system being useful, and therefore successful. However, non-use of a system does not necessarily indicate that it is not useful; it may simply indicate that the potential users have other tasks to perform (Seddon, 1997; Seddon \& Kiew, 1996). The construct 'net benefits' is most commonly measured using perceived usefulness or job impact at the individual level of analysis (Petter et al., 2008), hence, it was decided not to use 'net benefits'.

So far as the selection of DeLone and McLean IS success model $(1992,2003)$ as the basis of the research model and perceived trust, subjective norms, and attitude as the additional constructs are concerned, it is based on the several reasons: Firstly, it has been suggested that future research should examine how IS research models perform in various contexts, including settings from strictly voluntary to strictly involuntary use with recommended refinements as appropriate (Rai et al., 2002). Although prior studies (Etezadi-Amoli \& Farhoomad, 1996; Gelderman, 1998; Guimaraes \& Igbaria, 1997; Teng \& Calhoun, 1996; Wixom \& Watson, 2001) have tested this model on various success dimensions and their interrelationships, the success of the OPGRS has not been tested using this model yet. Secondly, agreeing from the arguments of Schaupp et al. (2009), we also advocate that subjective norms as the suitable construct to add to this model in the volitional context to better understand it. As subjective norm is defined as "the person's perceptions that most people who are important to him think he should or should not perform the behaviour in question" (Fishbein \& Ajzen 1975, p. 302), we believe that this construct will be a significant one in measuring the system's success.

Thirdly, deriving from the studies of Teo et al. (2008) and Khayun, Ractham, \& Firpo (2012), we believe that trust is one of the most important determinants to determine the perceptions about the information and system quality of the e-government websites being used. Moreover, in the context of an e-government system, which provides information and services to the users through a website, the perception is varied or diverse. Furthermore, it was also argued that website's quality is primarily based on trust, and the perceptions about it are stimulated by the prior interactions by the user. The role of trust in e-government is even more important also because the absence of adequate trust might motivate the users to revert to the traditional offline means of interacting with the government as it is unlikely to find alternative websites serving the same purpose. Therefore, building citizen's trust is supposed to be a key factor for the successful implementation of e-government websites (Teo et al., 2008; Warkentin, Gefen, Pavlou, \& Rose, 2002).

Lastly, as the TAM indicates that its key independent variables: perceived usefulness and perceived ease of use can determine or influence potential user's attitude toward behavioral intention (Davis, 1989; Lin et al., 2011). Venkatesh, Morris, Davis, \& Davis (2003) also found this construct as the strongest predictor of behavioral intention while analysing the independent models (i.e., theory of reasoned action (TRA), theory of planned behaviour (TPB)/decomposed theory of planned behaviour (DTPB), and Motivational Model). From the 
prior evidence of the models and performances of attitude as the mediating variable, we have decided to check its validity in our research model. Therefore, we are going to check the influence of quality variables, trust, and subjective norms firstly on attitude toward using the system, which latter decides the behavioral intention to use it.

Considering all the aspects of the IS success models of DeLone \& McLean $(1992,2003)$ and facts and arguments about their constructs, we have decided to consider the constructs including system quality, information quality, perceived trust, subjective norms, attitude toward using, intention to use, and user satisfaction to measure the success of the OPGRS. The proposed model is sketched and the corresponding hypotheses are formulated as under:

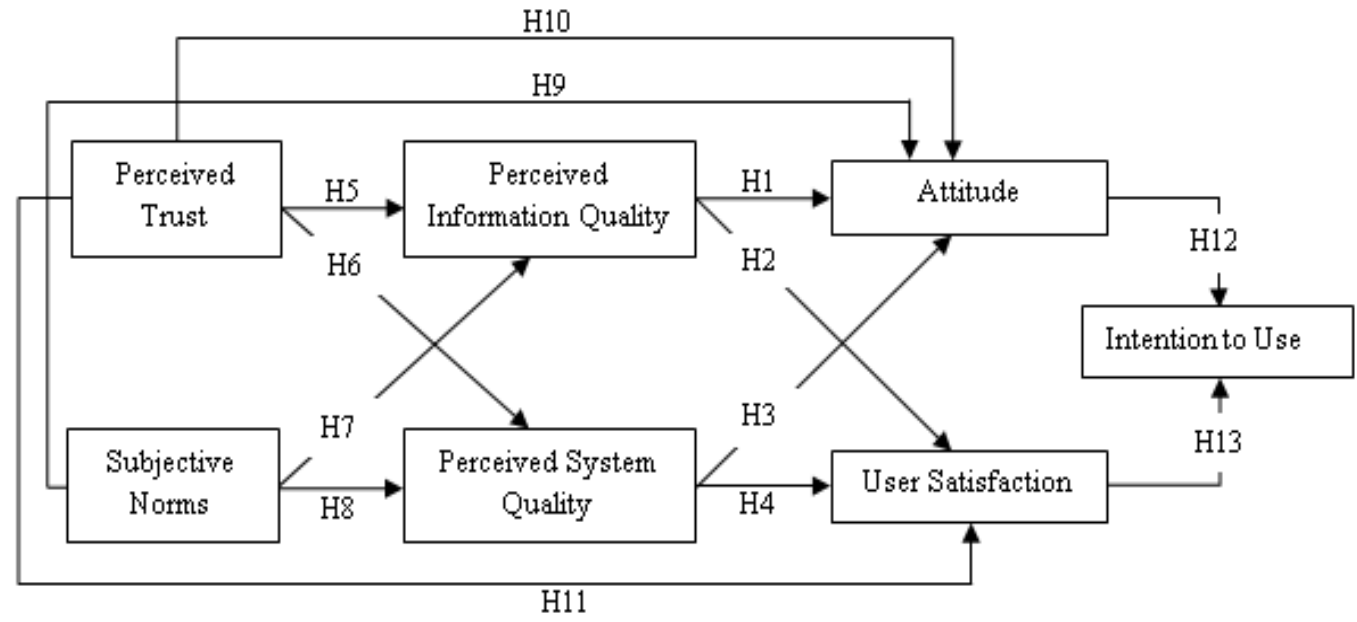

FIG. 1. The ProposedResearch Model

\section{Hypotheses Development}

Under the proposed research model, we have formulated 13 hypotheses based on the relationships between seven constructs adopted. A brief summary of the definitions for the core constructs used in the proposed research model is presented in Table 1.

TABLE 1

Definitions of core constructs used in proposed research model

\begin{tabular}{|l|l|}
\hline Variable/Construct & Definition \\
\hline System Quality & $\begin{array}{l}\text { System quality is concerned with whether or not there are 'bugs' in the system, } \\
\text { the consistency of the user interface, ease of use, quality of documentation, and } \\
\text { sometimes, quality and maintainability of the program code (Seddon, 1997). }\end{array}$ \\
\hline Information Quality & $\begin{array}{l}\text { Information quality is concerned with the issues such as the relevance, timeliness, } \\
\text { and accuracy of information generated by an information system. Not all } \\
\text { applications of IT involve the production of information for decision-making } \\
\text { (e.g., a word processor does not produce any information) so information quality } \\
\text { is not a measure that can be applied to all systems (Seddon, 1997). }\end{array}$ \\
\hline Subjective Norms & $\begin{array}{l}\text { The person's perception that most people who are important to him think he } \\
\text { should or should not perform the behavior in question (Ajzen, 1991; Fishbein \& } \\
\text { Ajzen, 1975). }\end{array}$ \\
\hline Attitude & $\begin{array}{l}\text { An individual's positive or negative feelings (evaluative affect) about performing } \\
\text { the target behaviour (Fishbein \& Ajzen 1975, p. 216). }\end{array}$ \\
\hline Trust & $\begin{array}{l}\text { Trust is defined as the belief that the trustee (i.e., government) will act } \\
\text { cooperatively to fulfil the trustor's (i.e., users of the government websites) } \\
\text { expectations without exploiting their vulnerabilities (Pavlou \& Fygenson, 2006). }\end{array}$ \\
\hline User Satisfaction & User satisfaction is the degree to which the user feels that the system meets his or \\
\hline
\end{tabular}


her information needs (Ives, Olson, \& Baroudi, 1983).

\section{Information Quality}

This variable is measured in terms of features related to actual information that is disseminated by information systems and the degree to which it matches with the user's expectations in terms of its accuracy, trustworthiness, significance, comprehensiveness, and succinctness (Bailey \& Pearson, 1983; Rai et al., 2002; Wang \& Strong, 1996). This attribute has been largely studied in the IS domain. For example, Zhang, Leeb, Huanga, Zhang, \& Huang (2005) argued that information quality as a key determinant of ERP success. This attribute has been explored quite regularly in context of e-government adoption research (e.g., Floropoulos et al., 2010; Lin et al., 2011; Shareef, Kumar, Kumar, \& Dwivedi, 2011) as well. DeLone \& McLean (2003) characterized information quality as relevant, complete, easy to understand, personalized, and secure determinant for assessing e-commerce systems success.

\section{System Quality}

The concept of system quality is related to the technical hierarchical level of group communication problems, which is all about how well the system transmits the sign of communication (Shannon \& Weaver, 1949). It is undertaken through the communication with the system when the user completes a specific task (Maes \& Poels, 2007). Irrespective of whatever knowledge the system holds, the characteristics of the system deriving from the literature are its flexibility, consistence, trustworthiness, usefulness of its particular functions, user-friendly interface, ease of use, and response time (Bailey \& Pearson, 1983; Doll \& Torkzadeh, 1988; Rai et al., 2002; Yusuf, Gunasekaran, \& Abthorpe, 2004). DeLone \& McLean (1992, 2003) described system quality as the required traits of the information systems itself.

\section{Perceived Trust}

Trust is a set of beliefs that tasks will be accomplished reliably (Sitkin \& Roth, 1993). The success of an e-government website is influenced by the citizen's trust in the government entity. An e-government website is an alternative for the government services provided to the citizens through the offline channels. Therefore, if the government takes an utmost care of its citizens and efficiently performs its services, the citizens would most likely to believe that the electronic services developed by the government will be able to cater their needs (Teo et al., 2008). So, a high degree of trust in the government website can augment citizens' belief that online transaction and transaction with government agencies can be conducted successfully (Khayun et al., 2012; Teo et al., 2008). In fact, trust is not only a one-time interaction, but must be built slowly and steadily as users continuously interact with the system (Gefen, Benbasat, \& Pavlou, 2008; Khayun et al., 2009).

\section{Subjective Norms}

The DeLone \& McLean Models $(1992,2003)$ do not specifically include any social variable. However, inclusion of such variable is crucial if it captures variance that is not previously explained by the other variables in the model (Mathieson, 1991). Subjective norms play an 
important role in the website settings because it reflects the likelihood of social influence of individual's decisions by his or her important ones. When others around an individual use a specific system and enjoy its benefits, there is a higher possibility that he or she will to use the system to attain same affects than others when a similar needs takes place (Schaupp et al., 2009). In line with the above arguments, we believe that subjective norms is such a social variable, which not only helps us analyse the success of the OPGRS system, but will also bring diversification in the IS success model among other constructs.

\section{User Satisfaction}

User satisfaction is regarded as the most common success measures of IS success (Seddon and Kiew, 1996). In the context of websites, user's satisfaction is crucial for instituting a long-term relationship and plays an important role in maintaining profitability and establishing an overall success for the website (Patterson, Johnson, \& Spreng, 1997). User satisfaction has been a persistent measure of IS success in general (e.g., Bhattacherjee, 2001; Conrath \& Mignen, 1990; Davis, Bagozzi, \& Warshaw, 1989; DeLone \& McLean, 1992; Gelderman, 1998; Ives \& Olson, 1984; McKinney, Yoon, \& Zahedi, 2002; MeLone, 1990; Rai et al., 2002; Schaupp et al., 2009; Venkatesh et al., 2003). Moreover, user satisfaction has also been regarded as a success metric in volitional contexts (Chen, 1999; DeLone \& McLean, 2004; McKinney et al., 2002; Schaupp et al., 2009). In line with the prior empirical research, user satisfaction with the OPGRS would be used as one of the measures of this egovernment systems success in this research.

\section{Attitude toward Using}

This factor measures individual's positive or negative feelings (evaluative effect) (Sahu \& Gupta, 2007) about using the OPGRS system. Ajzen \& Fishbein (1975) argued that a person's attitude toward an object influences the overall pattern of his or her responses toward that object, but it need not predict any given action. It was further analysed that a specific behaviour is rather determined by the intention to perform the behaviour in the question and this in turn is the function of his or her attitude toward performing the behavior. The concept of attitude evolutes from the TRA (Fishbein \& Ajzen, 1980) and also made it marks to the originally formulated TAM (Davis et al., 1989) in an attempt to understand why people accept or reject information systems.

The purpose of the TAM was to describe and envisage user acceptance of IS from measures taken after a concise period of interaction with the system. As per this model, a person's acceptance of an information system is determined by his or her intention to accept it, which in turn is determined by person's attitude toward the IS as one of the determinants (Davis et al., 1989; Sjazna, 1996). Deriving from the introduction of attitude as a mediating variable, many studies (e.g., Hung, Chang, \& Yu, 2006; Hung, Tang, Chang, \& Ke, 2009; Sahu \& Gupta, 2007; Schaper \& Pervan, 2007) used it as a determinant of behavioral intention. As this research also collects data from the respondents after a brief interaction with the system, it would be worthwhile to examine the quality measures, trust, and subjective norms firstly on the attitude followed by intention to use the system. 


\section{Perceived Information Quality $\rightarrow$ Attitude}

Given the information quality has been found to have a positive relationship with behavioral intention to use the system (DeLone \& McLean, 2003; Teo et al., 2008); the relationship is likely to hold true when the behavioral intention is surrogated with attitude toward using the system in question. As the data collected for the system in question i.e., OPGRS were through the potential adopters of the system after making them briefly introduced to the system, it is worthwhile to evaluate the influence of perceived information quality on the attitude of the users toward using the OPGRS system. Taking a sample of 465 used from the different organizations of the United States, Wixdom and Todd (2005) demonstrated that there was a strong correlation $(\mathrm{r}=0.67$ with $\mathrm{p}<0.001)$ between the information quality and attitude toward using an information system. With the moderating effect of social presence, Shin (2012) showed that the perceived information quality had a positive influence on the attitude of the 3DTV acceptance of the users. Deriving from the above arguments, we hypothesize that:

H1: Perceived information quality has a positive and significant impact on the attitude of the OPGRS systems users.

\section{Perceived Information Quality $\rightarrow$ User Satisfaction}

Several previous studies on IS success have demonstrated support for the argument that higher degree of information quality leads to enhanced user satisfaction (Chae \& Kim, 2001; Floropoulos et al., 2010; Iavari, 2005; McGill \& Hobbs, 2003; Rai et al., 2002; Rana et al., 2013b, Rana et al., 2013c; Seddon, 1997; Seddon \& Kiew, 1996; Wang \& Liao, 2008; Zhang et al., 2005). Petter \& McLean's (2009) meta-analytic assessment of DeLone and McLean model has also strongly supported in effect of information quality on user's satisfaction. In context of e-government adoption research, Wang \& Liao (2008) presented and validated a model of e-government system success (based on DeLone \& McLean (2003) IS success model) and found the influence of information quality on user satisfaction being significantly supported. Similar, results were obtained for TAXIS systems analysed by Floropoulos et al. (2010), where the findings indicated system quality as an important and stronger determinant of employee's satisfaction. Hence, we hypothesize:

H2: Perceived information quality has a positive and significant impact on the user's satisfaction of the OPGRS systems.

\section{Perceived System Quality Mttitude}

In line with the positive and strong evidence of the system quality on behavioral intention or use behaviour (DeLone \& McLean, 2003; Teo et al., 2008), we believe that it would be more appropriate to see the impact of perceived system quality on the attitude toward using the OPGRS system. This dependent variable is adopted also due to the fact that intention to use might be a more suitable variable in context of mandatory system use than its volitional context (DeLone \& McLean, 2003). Prior studies (e.g., Wang \& Liao, 2008; Wangpipatwong 
et al., 2009) on e-government adoption also supported this fact, where more number of studies (although not many studies have considered this model yet) were found to be significant on use behaviour than intention to use the e-government system. Moreover, Wixdom \& Todd (2005) also showed a strong positive correlation $(r=0.75$ with $\mathrm{p}<0.001)$ between the system quality and attitude toward using an information system. Moreover, system quality has been found consistently significant on the attitude in the context of 3DTV acceptance (Shin, 2009). Therefore, seeing intention to use and use behavior may not be functioning as the suitable dependent variables to measure the success of the OPGRS system due to the reasons of its volitional nature of use and the sample comprising of the potential adopters of the OPGRS system and attitude being already theorized as the significant determinant of system quality, we hypothesize that:

H3: Perceived system quality has a positive and significant effect on the attitude of the OPGRS system users.

\section{Perceived System Quality - User Satisfaction}

The prior empirical findings (Iavari, 2005; Rai et al., 2002; Rana et al., 2013b; Rana et al., 2013c; Seddon, 1997; Seddon \& Kiew, 1996; Wang \& Liao, 2008) have supported the positive and significant impact of system quality on user satisfaction as discussed in DeLone and McLean's model. That indicates that the higher levels of system quality are positively associated to higher levels of user satisfaction. However, analysing TAXIS in context of Greece, Floropoulos et al. (2010) found it non-significant. The authors argued that the system quality may not be the prominent factor in measuring satisfaction given the nature of sample being sufficiently computer and Internet literate. However, measuring the e-government system success using the validation of DeLone \& McLean model, Wang \& Liao (2008) found a significant impact of system quality on user's satisfaction. Therefore, we hypothesize that:

H4: Perceived system quality has a positive and significant impact on the user satisfaction of the OPGRS systems.

\section{Perceived Trust $\rightarrow$ Perceived Information Quality}

Information quality signifies citizen's evaluation of whether the information on the website is accurate, valid, and timely. A lack of citizens' trust in the e-government website will cause them concerns about the accurate and timely publication of government information and policies and whether the corresponding information is trustworthy and best to their interests (Teo et al., 2008). Khayun et al. (2012) argued that the perception of information quality is based on the trusting beliefs of the citizens towards the e-government system. Prior research in the other contexts has consistently showed that the positive influence of the trust between the partners depends on the perceived accuracy of the information (Benton, Gelber, Kelley, \& Liebling, 1969; Khayun et al., 2012; Roberts \& O'Reilly, 1974). Therefore, the perceived information quality of the OPGRS systems should vary based on the level of citizen's trust. Hence, we hypothesize:

H5: Perceived trust is positively and significantly associated with the perceived information quality of the OPGRS systems. 


\section{Perceived Trust $\rightarrow$ Perceived System Quality}

Prior research on the other contexts found that higher levels of trust to be positively linked with the performance perceptions of the different organizational systems (Lind, Tyler, \& Huo, 1997; Rousseau \& Tijoriwala, 1999). In the context of e-commerce, trust was argued diminishing customers' need to realize, observe, and manage the situation for making online transaction effortless (Pavlou, 2003). Examining the success of e-Excise system, Khayun et al. (2012) showed that trust in e-government websites was positively associated with the perception of system quality. Moreover, Teo et al. (2008) argued that as citizens are not much aware about the detailed technical aspects and different benchmarks for an e-government websites, their trust perception toward such systems enables them to believe that the concerning government will effectively deal with the various technical issues for enhancing the systems usability. Extrapolating from the above arguments, we hypothesize:

H6: Perceived trust is positively and significantly associated with the perceived system quality of the OPGRS systems.

\section{Subjective Norms $\rightarrow$ Perceived Information Quality}

Examining the success of websites beyond e-commerce, Schaupp et al. (2009) argued subjective norms as the suitable construct to add in context of the volitional context. They advocated the inclusion of subjective norms construct in the DeLone \& McLean IS success model (1992) to better understand the user behaviour in the volitional context of the system's use. It was further argued that subjective norms is considered significant in the website settings as it reflects the probability of social influence on individual's decision making by his or her referent ones (Schaupp et al., 2009). The authors found the impact of subjective norms on information quality as significant for the online community site. However, this path was obtained as non-significant for e-commerce site. Analysing the difference between these two outcomes, it was discussed that as the online community is public and common to all, users refer it to one another, whereas e-commerce website caters to the specific transactional needs and purchase experience of the users and therefore hardly influenced by the referent others (Schaupp et al., 2009). As the OPGRS is a common system being used by every individual for lodging complaints, we believe that social factors such as subjective norms would influence the perceived information quality of the system. Hence, we hypothesize:

H7: Subjective norms will positively and significantly influence the perceived information quality of the OPGRS systems.

\section{Subjective Norms $\rightarrow$ Perceived System Quality}

Similar to the line of arguments for the impact of subjective norms on perceived information quality, it was argued that subjective norms will have the same significant impact on the perceived system quality. This relationship was empirically examined for systems including 
online community site as well as e-commerce site. And, the impact of subjective norms on perceived system quality was found to be significant for the online community site because of the belief that the individual's referent others were supposed to be influenced his or her suggestions (Schaupp et al., 2009). In line with the above arguments, we also acknowledge that as OPGRS is an e-government system, the user's positive experience and benefits obtained from it would allow his or her important one's to positively comprehend its system quality. Therefore, we hypothesize:

H8: Subjective norms will positively and significantly influence the perceived system quality of the OPGRS systems.

\section{Subjective Norms $\rightarrow$ Attitude}

Kelman $(1958,1974)$ suggested an indirect impact of subjective norms on intention called internalization. Internalization refers to the process through which an individual includes the important referents' beliefs into one's own belief structure. Therefore, subjective norms would directly impact one's beliefs and attitude, and indirectly influence intentions ( $\mathrm{Li}$ et al., 2008). For example, Venkatesh and Davis (2000) proposed that when one's important referents believe that the system is useful, an individual thinks that the system is really useful and in turn intend to use it. Similarly, Li, Hess, \& Valachich (2006) found a direct relationship between subjective norms and attitude in an IS context. Li, Hess, \& Valachich (2008) argued that when the users have not enough knowledge about the system in question, they might rely on the important referent's opinions and might and might adopt the referent's beliefs into their own trusting attitude. Deriving from the above arguments, we hypothesize:

H9: Subjective norms will have a positive and significant influence on the attitude of using the OPGRS systems.

\section{Perceived Trust $\rightarrow$ Attitude}

Both trust and technology acceptance antecedents have been studied for years in conventional physical commercial environments. In the marketing and management literature, trust was found to be strongly associated with attitude toward product and services and toward purchasing behaviours (Gefen, Karahanna, \& Straub, 2003). Considering the case of the online tax filing and payment systems of Taiwan, Hung et al. (2006) showed that attitude is influenced by trust. Similarly, Hung et al. (2009) also found that individual's trust significantly and positively influenced one's attitude toward acceptance of e-government's electronic document management systems. Deriving from the above arguments, we hypothesize:

H10: Subjective norms will significantly and positively influence user's attitude toward using the OPGRS systems.

\section{Perceived Trust $\rightarrow$ User Satisfaction}

Several studies (Balasubramanian, Konana, \& Menon, 2003; Grewal, Comer, \& Mehta, 1999; Ratnasingham, 1998a) have demonstrated that trust influences satisfaction directly. In the 
consumer behaviour literature, Chakravarty, Feinberg, \& Widdows (1997) found that respondent's considered trust was the most significant factor in determining consumers' satisfaction with their banks. In the context of e-commerce, a number of studies (e.g., Balasubramanian et al. 2003, Flavian, Guinaliu, \& Gurrea, 2006; Kim, Park, \& Jeong, 2004; Kim, Ferrin, \& Rao, 2009; Lee \& Chung, 2009) have researched on Internet consumers' trust and/or satisfaction as the crucial factors for the success of partner relationships. For example, Ratnasingham (1998b) stated trust as the required ingredient of e-commerce for creating loyal and satisfied customers. Similarly, Balasubramanian et al. (2003) argued that higher levels of investor's trust in an online broker directed to a greater satisfaction. Using DeLone and McLean's model to understand the factors influencing the trust in and satisfaction with mobile banking in Korea, Lee \& Chung (2009) found trust to be the significant determinant of the customer's satisfaction. Based on the above arguments, we also believe that perceived trust would positively contribute to the users' satisfaction. Therefore, we hypothesize:

H11: User's Perceived trust on the OPGRS systems will positively contribute to his or her satisfaction.

\section{Attitude $\rightarrow$ Intention to Use}

According to Ajzen \& Fishbein (1972), attitude is one of the important factors on the behavioral intention formation, a proposition that is supported by the TAM. Users with a more positive attitude toward information technology are likely to be more satisfied with the system (Ajzen \& Fishbein, 1980; Heeks, 2006; Shin, 2007). The e-government literature (e.g., Chu, Hsiao, Lee, \& Chen, 2004; Hung et al., 2006; Hung et al., 2009; Lu, Huang, \& Lo, 2010) have also found the relationship between attitude and intention to use the corresponding system as significant. The weight-analysis literature of e-government system indicates that out of 15 relationships explored between attitude and intention to use, 14 were found significant (Rana, Dwivedi, \& Williams, 2014). The meta-analysis for this relationship conducted using the e-government literature also supported its significance (Rana, Dwivedi, $\&$ Williams, 2013d). Therefore, deriving from the above arguments, we hypothesize:

H12: User's attitude will have a positive and significant influence on intention to use the OPGRS systems.

\section{User Satisfaction $\rightarrow$ Intention to Use}

The association between satisfaction and continue using the IS in the DeLone \& McLean model can be explained through the feedback mechanism where satisfaction, as an affective circumstance created from the previous use, will persuade user's intention to continue using the website in the future (Teo et al., 2008). Prior research has also explained the satisfactionintention link based on the TRA where satisfaction was conceptualized as an attitude preceding the actual behavior (Rai et al., 2002). Considering the context of e-government, Teo et al. (2008) also argued that if a citizen has gone through an easy and satisfying experience of finding the information needed from the system, it is more like that the system would be used next time for obtaining similar information. McGorry (2003) argued that student satisfaction with the online learning courses was likely to determine whether the 
student would consider subsequent courses. Chiu, Hsu, Sun, Lin, \& Sun (2005) found that learner's satisfaction with the web-based learning was significantly associated with their continuance intentions. Therefore, we hypothesize:

H13: User's satisfaction will positively and significantly influence his or her intention to use the OPGRS systems.

A brief summary of hypotheses is presented in Table 2 as follows:

TABLE 2

A brief summary of hypotheses of the proposed research model

\begin{tabular}{l|l}
\hline H\# & Hypothesis \\
\hline H1 & Perceived information quality has a positive and significant relationship with attitude \\
H2 & Perceived information quality has a positive and significant relationship with user satisfaction \\
H3 & Perceived system quality has a positive and significant relationship with attitude \\
H4 & Perceived system quality has a positive and significant relationship with user satisfaction \\
H5 & Perceived trust will positively and significantly influence perceived information quality \\
H6 & Perceived trust will positively and significantly influence perceived system quality \\
H7 & Subjective norms has a positive and significant relationship with perceived information quality \\
H8 & Subjective norms has a positive and significant relationship with perceived system quality \\
H9 & Subjective norms has a positive and significant relationship with attitude of using the system \\
H10 & Perceived trust has a positive and significant relationship with attitude of using the system \\
H11 & Perceived trust has a positive and significant relationship with user satisfaction \\
H12 & Attitude has a positive and significant relationship with intention to use the system \\
H13 & User satisfaction has a positive and significant relationship with intention to use the system \\
\hline
\end{tabular}

\section{RESEARCH METHODOLOGY}

For the purpose of examining the success of the OPGRS system, we considered survey as an appropriate research method (Cornford \& Smithson, 1996; Choudrie \& Dwivedi, 2005). There are various ways to capture the data, however, a self-administered questionnaire was found to be suitable as a primary survey instrument of data collection in this research. This is due to the fact that this method takes care of the issue of reliability of information by reducing and eliminating the way the questions are asked and presented (Conford \& Smithson, 1996). Moreover, collecting data from the majority of respondents within a short and specific period of time was a critical issue of this research (Fowler, 2002). Therefore, only closed and multiple-choice questions were included in the questionnaire. The final questionnaire consisted of total 38 questions including 10 questions from respondent's demographic characteristics and 28 questions on the seven different constructs of the proposed research model. All these questions were multiple-type, closed-ended and sevenpoint Likert scale type questions. Likert scales (1-7) with anchors ranging from "strongly disagree" to "strongly agree" (Wang \& Liao, 2008) were used for all non-demographic based questions.

The sample of the study consists of wide array of respondents from different cities of India including New Delhi, Pune, Mumbai, Bangalore, Patna, Siliguri, and Gangtok. Initially, a preliminary version of the questionnaire was tested on the 32 respondents including staff and postgraduate students of an academic institution in India to verify its appropriateness and comprehensiveness. A few trivial changes were made to the questionnaire on the feedback received from the respondents. Finally, a total of 1500 questionnaires were distributed to the respondents in the seven cities in the course of one and half month duration. The data related 
to the adoption of the OPGRS system were collected only through the non-adopters of the system. This was done purposefully realizing the fact that the system is relatively new and majority of the population of the country is not aware of its use and benefits even though they have grievances in their day-to-day lives.

However, most of the respondents in this research are well acquainted with the computer system and Internet technology and have been using it for quite some time. All the respondents were briefed and demonstrated about the functioning of the OPGRS at one-toone or group basis and in some cases they were given maximum two days of time to complete the questionnaire. However, some of the questionnaires were made to respond on spot. A total of 485 completed survey questionnaires were returned to us. The further scrutiny of questionnaires revealed that 66 of them were partially completed and so rejected from the subsequent analysis. Hence, we were left out with 419 usable responses, which made the basis for our empirical analysis for measuring the success of the OPGRS system. The overall response rate was found to be $32.3 \%$ with $27.9 \%$ valid questionnaires.

\section{FINDINGS}

\section{Demographic Profile}

This section analyses demographic data (in Table 3) obtained from the respondents. As per the questionnaire results, the average respondent's age ranges from 20 to 34, with males accounting for $67.8 \%$ of the sample and $32.2 \%$ were female. The majority of the population (56.1\%) belongs to student community with a fair representation from public- and private sector employees (29.3\%). As far as the educational qualifications are concerned, $82 \%$ of the total population are having a minimum degree of graduation. The computer and Internet literacy and awareness of the respondents can be judged from their very high computer and Internet experience percentage $(\approx 96 \%)$. This higher frequency is also supported by their computer and Internet access at various places and Internet use frequency, which is very high. Therefore, it is argued that the sample of respondents could be the best-fit potential users and adopters of the systems such as online public grievance redressal system.

TABLE 3

Demographic characteristics of respondents

\begin{tabular}{|l|c|c|}
\hline Characteristics & Frequency & Percentage \\
\hline Age & $\mathbf{( \# )}$ & $\mathbf{( \% )}$ \\
\hline 20-24 Years & 228 & 54.4 \\
\hline 25-29 Years & 70 & 16.7 \\
\hline 30-34 Years & 52 & 12.4 \\
\hline 35-39 Years & 27 & 6.4 \\
\hline 40-44 Years & 11 & 2.6 \\
\hline 45-49 Years & 13 & 3.1 \\
\hline 50-54 Years & 7 & 1.7 \\
\hline 55-59 Years & 1 & 0.2 \\
\hline$>=60$ Years & 10 & 2.4 \\
\hline Gender & & \\
\hline Male & 284 & 67.8 \\
\hline Female & 135 & 32.2 \\
\hline Education & 7 & \\
\hline Non-Matriculation & & 1.7 \\
\hline
\end{tabular}




\begin{tabular}{|c|c|c|}
\hline Matriculation & 13 & 3.1 \\
\hline $10+2 /$ Intermediate & 55 & 13.1 \\
\hline Graduate & 161 & 38.4 \\
\hline Post-Graduate & 169 & 40.3 \\
\hline Post-Graduate Research & 14 & 3.3 \\
\hline \multicolumn{3}{|l|}{ Occupation } \\
\hline Student & 235 & 56.1 \\
\hline Unemployed & 18 & 4.3 \\
\hline Pensioner & 7 & 1.7 \\
\hline Employee-Public Sector & 29 & 6.9 \\
\hline Employee-Private Sector & 94 & 22.4 \\
\hline Self-Employed & 36 & 8.6 \\
\hline \multicolumn{3}{|l|}{ Computer Access } \\
\hline Home & 273 & 46.4 \\
\hline Office & 107 & 18.2 \\
\hline Internet Cafe & 83 & 14.1 \\
\hline College/University & 100 & 17.0 \\
\hline Common Service Centre & 12 & 2.0 \\
\hline No Access & 13 & 2.2 \\
\hline \multicolumn{3}{|c|}{ Computer Experience (in Years) } \\
\hline No Experience & 17 & 4.1 \\
\hline 1-3 Years & 99 & 23.6 \\
\hline 4-6 Years & 98 & 23.4 \\
\hline 7-9 Years & 91 & 21.7 \\
\hline$>=10$ Years & 114 & 27.2 \\
\hline \multicolumn{3}{|l|}{ Internet Access } \\
\hline Home & 246 & 42.6 \\
\hline Office & 104 & 18.0 \\
\hline Internet Cafe & 109 & 18.9 \\
\hline College/University & 103 & 17.8 \\
\hline Common Service Centre & 10 & 1.7 \\
\hline No Access & 6 & 1.0 \\
\hline \multicolumn{3}{|c|}{ Internet Experience (in Years) } \\
\hline No Experience & 16 & 3.8 \\
\hline 1-3 Years & 132 & 31.5 \\
\hline 4-6 Years & 122 & 29.1 \\
\hline 7-9 Years & 80 & 19.1 \\
\hline$>=10$ Years & 69 & 16.5 \\
\hline \multicolumn{3}{|l|}{ Internet Use Frequency } \\
\hline Never & 12 & 2.9 \\
\hline Very Rarely & 21 & 5.0 \\
\hline Rarely & 39 & 9.3 \\
\hline Occasionally & 77 & 18.4 \\
\hline Very Frequently & 137 & 32.7 \\
\hline Always & 133 & 31.7 \\
\hline
\end{tabular}

\section{Reliability Analysis - Cronbach's Alpha ( $\alpha$ )}

Reliability analysis was performed using Cronbach's alpha. It was used for determining the reliability of the scale, which provides an indication about the internal consistency of the items measuring the same construct (Hair, Anderson, Tatham, \& Black, 1992; Zikmund, 1994). Cronbach's alpha reliability for all the constructs except system quality is in the range 0.796-0.902, which is quite good. A Chronbach's alpha $(\alpha)$ of greater than 0.7 is considered to be good (Nunnaly, 1978; Hair et al., 1992). Therefore, alphas imply strong reliability for all constructs, but system quality, which is at satisfactory level. According to Hinton et al. (2004), there are four cut-offs for Cronbach's alpha representative of reliability, which are (i) 
0.90 indicates the excellent reliability, (ii) $0.70-0.90$ indicates the high reliability, (iii) 0.50 0.70 reflects moderate reliability, and (iv) 0.50 and below represent the low reliability. Table 4 presents the Cronbach's alpha for all the seven variables.

TABLE 4

Cronbach's alpha $(\alpha)$ of constructs

\begin{tabular}{|l|c|c|c|c|}
\hline Constructs & $\begin{array}{c}\text { Sample } \\
\text { Size }\end{array}$ & $\begin{array}{c}\text { \# of } \\
\text { Items }\end{array}$ & $\begin{array}{c}\text { Cronbach's } \\
\text { Alpha (a) }\end{array}$ & $\begin{array}{c}\text { Reliability } \\
\text { Type }\end{array}$ \\
\hline Perceived System Quality (SQ) & 419 & 3 & 0.548 & Moderate \\
\hline Perceived Information Quality (IQ) & 419 & 9 & 0.902 & Excellent \\
\hline Attitude (AT) & 419 & 4 & 0.843 & High \\
\hline Intention to Use (IU) & 419 & 3 & 0.796 & High \\
\hline User Satisfaction (US) & 419 & 4 & 0.881 & High \\
\hline Perceived Trust (PT) & 419 & 3 & 0.854 & High \\
\hline Subjective Norms (SN) & 419 & 2 & 0.767 & High \\
\hline
\end{tabular}

\section{Descriptive Statistics}

Table 5 presents the mean and standard deviation (S.D.) for all the seven constructs. The higher average means for most of the constructs indicate that respondents react favourably to the IS success measures examined. The table indicates that attitude is the construct with the highest average mean of 5.59. This is followed by intention to use, perceived system quality, perceived trust, and perceived information quality. However, user satisfaction is seen to be the least agreed-upon construct with the lowest average mean of 4.15.

TABLE 5

Descriptive statistics of the constructs and their items

\begin{tabular}{|l|c|c|c|c|}
\hline Constructs & $\#$ & N & Mean & S.D. \\
\hline Perceived System Quality (SQ) & 419 & 3 & 5.19 & 0.97 \\
\hline Perceived Information Quality (IQ) & 419 & 9 & 5.03 & 0.99 \\
\hline Perceived Trust (PT) & 419 & 3 & 5.10 & 1.15 \\
\hline Subjective Norms (SN) & 419 & 2 & 4.86 & 1.37 \\
\hline Attitude (AT) & 419 & 4 & 5.59 & 1.11 \\
\hline Intention to Use (IU) & 419 & 3 & 5.26 & 1.23 \\
\hline User Satisfaction (US) & 419 & 4 & 4.15 & 0.95 \\
\hline
\end{tabular}

[Note: \# = Number of Usable Responses, $\mathrm{N}=$ Number of Items, S.D. = Standard Deviation]

\section{Hypotheses Testing}

A total of 13 research hypotheses (see Table 2 and Figure 1) were assessed to understand whether all independent variables positively and significantly explained the dependent variables. Our analysis indicated that all the 13 hypotheses were supported by the data, which suggested that all independent variables (i.e., perceived trust, subjective norms, perceived information quality, perceived system quality, attitude, and user satisfaction) explained the dependent variables (i.e., perceived information quality, perceived system quality, attitude, user satisfaction, and intention to use) under different circumstances. A detailed analysis of this is provided under the remaining paragraphs of this subsection. Table $6,7,8,9$, and 10 present output of linear regression model and Table 11 demonstrates the correlation model analysed using SPSS 19.0.

The analysis presented in Table 6 supported all the hypotheses (i.e. H1, H3, H9, and H10) on attitude as positive and significant. The constructs IQ, SQ, PT, and SN explain 30.2\% 
(adjusted $\mathrm{R}^{2}$ ) of the variance in respondents' attitude toward using the OPGRS systems. Since, the overall model is significant $(\mathrm{F}=46.141, \mathrm{p}=0.000)$, the significance of the independent variable was further examined. The independent variables such as SQ and SN were found significant with $0.1 \%$ significance level, whereas IQ and PT were found significant with $1 \%$ significance level. Therefore, all the four hypotheses H1, H3, H9, and H10 are supported.

TABLE 6

Effect of information quality, system quality, trust, and subjective norms on attitude

\begin{tabular}{|c|c|c|c|c|c|c|}
\hline \multirow[t]{2}{*}{ Model } & \multicolumn{2}{|c|}{ Unstandardized Coefficients } & \multirow{2}{*}{$\frac{\begin{array}{c}\text { Standardized } \\
\text { Coefficients }\end{array}}{\text { Beta }}$} & \multirow[t]{2}{*}{$\mathrm{t}$} & \multirow[t]{2}{*}{ Sig. } & \multirow[t]{2}{*}{ Result } \\
\hline & $\mathrm{B}$ & Std. Error & & & & \\
\hline (Constant) & 2.373 & 0.280 & & 8.484 & 0.000 & \\
\hline IQ & 0.201 & 0.064 & $0.179 * *$ & 3.150 & 0.002 & Supported (H1) \\
\hline SQ & 0.317 & 0.060 & $0.278 * * *$ & 5.318 & 0.000 & Supported (H3) \\
\hline PT & 0.130 & 0.048 & $0.135 * *$ & 2.715 & 0.007 & Supported (H9) \\
\hline $\mathrm{SN}$ & 0.251 & 0.038 & $0.310 * * *$ & 6.680 & 0.000 & Supported (H10) \\
\hline$\overline{\text { Model R }}{ }^{2}$ & 0.308 & & & & & \\
\hline Adjusted $\mathrm{R}^{2}$ & 0.302 & & & & & \\
\hline $\bar{F}$ & 46.141 & & & & & \\
\hline$\overline{\text { Significance }}$ & 0.000 & & & & & \\
\hline
\end{tabular}

Table 7 presents the $\beta$-value of independent variables such as IQ, SQ, and PT on US. The analysis exhibits a stronger effect of IQ $(\beta=0.343)$ and PT $(\beta=0.265)$ on user satisfaction than attitude, however, SQ $(\beta=0.239)$ on user satisfaction seemed to be less impacting than attitude toward using the OPGRS systems. This indicates that higher the perceived trust and perceived information quality higher the user satisfaction than merely the user's attitude toward using the system. The overall significance further reflects that the OPGRS system enhances user's satisfaction perception by promising to provide them the accurate, reliable, and updated information along with their perceived trust and the system quality for the system. The higher explained variance of $49.4 \%$ (adjusted $\mathrm{R}^{2}$ ) on users' satisfaction by IQ, SQ, and PT describe the rationale of possible success for the OPGRS systems. This is due to the fact the user's satisfaction is considered to be one of the important measures for any system's success.

TABLE 7

Effect of information quality, system quality, and trust on user satisfaction

\begin{tabular}{|c|c|c|c|c|c|c|}
\hline \multirow[t]{2}{*}{ Model } & \multicolumn{2}{|c|}{ Unstandardized Coefficients } & \multirow{2}{*}{$\begin{array}{c}\begin{array}{c}\text { Standardized } \\
\text { Coefficients }\end{array} \\
\text { Beta }\end{array}$} & \multirow[t]{2}{*}{$\mathrm{t}$} & \multirow{2}{*}{ Sig. } & \multirow{2}{*}{ Result } \\
\hline & $\mathrm{B}$ & Std. Error & & & & \\
\hline (Constant) & 0.206 & 0.252 & & 0.816 & 0.415 & \\
\hline IQ & 0.412 & 0.056 & $0.343 * * *$ & 7.398 & 0.000 & Supported (H2) \\
\hline SQ & 0.292 & 0.054 & $0.239 * * *$ & 5.405 & 0.000 & Supported (H4) \\
\hline PT & 0.273 & 0.044 & $0.265 * * *$ & 6.263 & 0.000 & Supported (H11) \\
\hline Model R ${ }^{2}$ & 0.498 & & & & & \\
\hline Adjusted $\mathrm{R}^{2}$ & 0.494 & & & & & \\
\hline F & 137.179 & & & & & \\
\hline Significance & 0.000 & & & & & \\
\hline
\end{tabular}


All the three hypotheses $\mathrm{H} 2, \mathrm{H} 4$, and $\mathrm{H} 11$ have been found positive and significant on the user satisfaction. The overall model was found significant $(\mathrm{F}=137.179, \mathrm{p}=0.000)$, and the significance of the individual independent variables was further verified. It was found that all IQ, SQ, and PT were found significant on the US with 0.001 significant levels.

Table 8 summarizes the results of the hypotheses testing the dependent variable called perceived information quality. This model explains $37.8 \%$ (adjusted $\mathrm{R}^{2}$ ) of variance of the system OPGRS on respondent's perceived information quality. Again, the overall model was found significant $(\mathrm{F}=128.093, \mathrm{p}=0.000)$ with the individual independent variables PT and SN are significant determinants of respondent's perceived information quality with a significance level of 0.001 .

TABLE 8

Effect of trust and subjective norms on information quality

\begin{tabular}{|c|c|c|c|c|c|c|}
\hline \multirow{2}{*}{ Model } & \multicolumn{2}{|c|}{ Unstandardized Coefficients } & \multirow{2}{*}{$\begin{array}{c}\begin{array}{c}\text { Standardized } \\
\text { Coefficients }\end{array} \\
\text { Beta }\end{array}$} & \multirow{2}{*}{$\mathrm{t}$} & \multirow{2}{*}{ Sig. } & \multirow{2}{*}{ Result } \\
\hline & $\mathrm{B}$ & Std. Error & & & & \\
\hline (Constant) & 1.989 & 0.194 & & 10.241 & 0.000 & \\
\hline PT & 0.375 & 0.035 & $0.437 * * *$ & 10.795 & 0.000 & Supported (H5) \\
\hline SN & 0.233 & 0.029 & $0.322 * * *$ & 7.956 & 0.000 & Supported (H7) \\
\hline Model R ${ }^{2}$ & 0.381 & & & & & \\
\hline Adjusted $\mathrm{R}^{2}$ & 0.378 & & & & & \\
\hline $\mathrm{F}$ & 128.093 & & & & & \\
\hline Significance & 0.000 & & & & & \\
\hline
\end{tabular}

More precisely, the hypotheses $\mathrm{H} 5$ and $\mathrm{H} 7$ are supported. This time, PT exhibits stronger effect $(\beta=0.437)$ on perceived information quality than $\mathrm{SN}(\beta=0.322)$. This indicates that perceived trust about the system leaves higher impression about the possible accuracy, reliability, relevance, and timeliness of information (i.e., information quality) of the system than the same being created by the influence of our referent ones.

Table 9 summarizes the results of the hypotheses testing on the dependent variable system quality. This model explains $26.8 \%$ (adjusted $\mathrm{R}^{2}$ ) of variance of the system OPGRS on respondent's perception about the system quality. Again, the overall model was found significant $(\mathrm{F}=77.479, \mathrm{p}=0.000)$ with the individual independent variables $\mathrm{PT}$ and $\mathrm{SN}$ are significant determinants of respondent's perceived system quality with a significance level of 0.001. The impact of PT (with $\beta=0.395)$ and $\mathrm{SN}(\beta=0.239)$ on perceived system quality is proportionately same as it was on information quality. However, the degree of influence of these independent factors (i.e., PT and SN) on perceived system quality is relatively less though significant at 0.001 levels than that of perceived information quality under the similar circumstances. 
TABLE 9

Effect of trust and subjective norms on system quality

\begin{tabular}{|c|c|c|c|c|c|c|}
\hline \multirow{2}{*}{ Model } & \multicolumn{2}{|c|}{ Unstandardized Coefficients } & \multirow{2}{*}{$\begin{array}{c}\begin{array}{c}\text { Standardized } \\
\text { Coefficients }\end{array} \\
\text { Beta }\end{array}$} & \multirow{2}{*}{$\mathrm{t}$} & \multirow{2}{*}{ Sig. } & \multirow{2}{*}{ Result } \\
\hline & $\mathrm{B}$ & Std. Error & & & & \\
\hline (Constant) & 2.655 & 0.207 & & 12.804 & 0.000 & \\
\hline PT & 0.334 & 0.037 & $0.395 * * *$ & 8.996 & 0.000 & Supported (H6) \\
\hline SN & 0.170 & 0.031 & $0.239 * * *$ & 5.445 & 0.000 & Supported (H8) \\
\hline$\overline{\text { Model R }}{ }^{2}$ & 0.271 & & & & & \\
\hline$\overline{\text { Adjusted } \mathrm{R}^{2}}$ & 0.268 & & & & & \\
\hline$\overline{\mathrm{F}}$ & 77.479 & & & & & \\
\hline$\overline{\text { Significance }}$ & 0.000 & & & & & \\
\hline
\end{tabular}

Table 10 summarizes the results of the hypotheses testing for the dependent variable intention to use. This model explains $42.9 \%$ of the variance from the users' intention to use the OPGRS systems. Again the overall model was significant with the F's highest $(\mathrm{F}=157.927$, $\mathrm{p}=0.000$ ) value, and we further tested the significance of each independent variable. The findings indicated that AT and US are the significant determinants of users' intention to use the OPGRS systems.

TABLE 10

Effect of attitude and user satisfaction on intention to use

\begin{tabular}{|c|c|c|c|c|c|c|}
\hline \multirow{2}{*}{ Model } & \multicolumn{2}{|c|}{ Unstandardized Coefficients } & \multirow{2}{*}{$\begin{array}{c}\begin{array}{c}\text { Standardized } \\
\text { Coefficients }\end{array} \\
\text { Beta }\end{array}$} & \multirow{2}{*}{$\mathrm{t}$} & \multirow{2}{*}{ Sig. } & \multirow{2}{*}{ Result } \\
\hline & $\mathrm{B}$ & Std. Error & & & & \\
\hline (Constant) & 0.859 & 0.271 & & 3.172 & 0.002 & \\
\hline AT & 0.683 & 0.043 & $0.617 * * *$ & 15.986 & 0.000 & Supported (H12) \\
\hline US & 0.113 & 0.040 & $0.109 * *$ & 2.827 & 0.005 & Supported (H13) \\
\hline Model R ${ }^{2}$ & 0.432 & & & & & \\
\hline Adjusted $\mathrm{R}^{2}$ & 0.429 & & & & & \\
\hline $\mathrm{F}$ & 157.927 & & & & & \\
\hline Significance & 0.000 & & & & & \\
\hline
\end{tabular}

More specifically, hypotheses H12 and H13 are supported. Here, AT (with $\beta=0.617$ ) showed the much stronger effect on intention to use than US $(\beta=0.109)$, however, both of them were found significant at $0.1 \%$ levels.

Table 11 presents the correlation between all possible pair of seven constructs. The findings indicated that all variables were positively correlated with one another with a correlation ranging from 0.186 to 0.649 . The most important of all were the correlations between AT and BI (0.649), IQ and US (0.626), IQ and SQ (0.592), SQ and US (0.566), and PT and US (0.560). All the variables have positive correlations at the $1 \%$ significance level. The relatively high correlations between the IS success constructs were expected and confirm the prior research on the relationships between the IS success variables (Hussein et al., 2007; Rai et al., 2002; Seddon and Kiew, 1996). 
TABLE 11

Correlations and AVE

\begin{tabular}{clllllll}
\hline VAR & \multicolumn{1}{c}{ IQ } & \multicolumn{1}{c}{ SQ } & \multicolumn{1}{c}{ PT } & SN & AT & US & BI \\
\hline IQ & $\mathbf{1 . 0 0 0}$ & & & & & & \\
SQ & $0.592^{* *}$ & $\mathbf{1 . 0 0 0}$ & & & & & \\
PT & $0.536^{* *}$ & $0.468^{* *}$ & $\mathbf{1 . 0 0 0}$ & & & & \\
SN & $0.456^{* *}$ & $0.360^{* *}$ & $0.305^{* *}$ & $\mathbf{1 . 0 0 0}$ & & & \\
AT & $0.412^{* *}$ & $0.432^{* *}$ & $0.186^{* *}$ & $0.450^{* *}$ & $\mathbf{1 . 0 0 0}$ & & \\
US & $0.626^{* *}$ & $0.566^{* *}$ & $0.560^{* *}$ & $0.286^{* *}$ & $0.288^{* *}$ & $\mathbf{1 . 0 0 0}$ & \\
BI & $0.373^{* *}$ & $0.427^{* *}$ & $0.214^{* *}$ & $0.386^{* *}$ & $0.649^{* *}$ & $0.287^{* *}$ & $\mathbf{1 . 0 0 0}$ \\
\hline
\end{tabular}

[Notes: VAR: Variables, ${ }^{* *}$ : Correlation is significance at the $1 \%$ level (2-tailed), Diagonal elements (in bold) are the square root of the Average Variance Extracted (AVE), off-diagonal elements are the correlations among constructs]

The hypothesis testing results of linear regression analysis with the coefficient values (i.e. $\beta$ value), $\mathrm{p}$-value, and $\mathrm{R}^{2}$-value are presented along the research model in figure 2 .

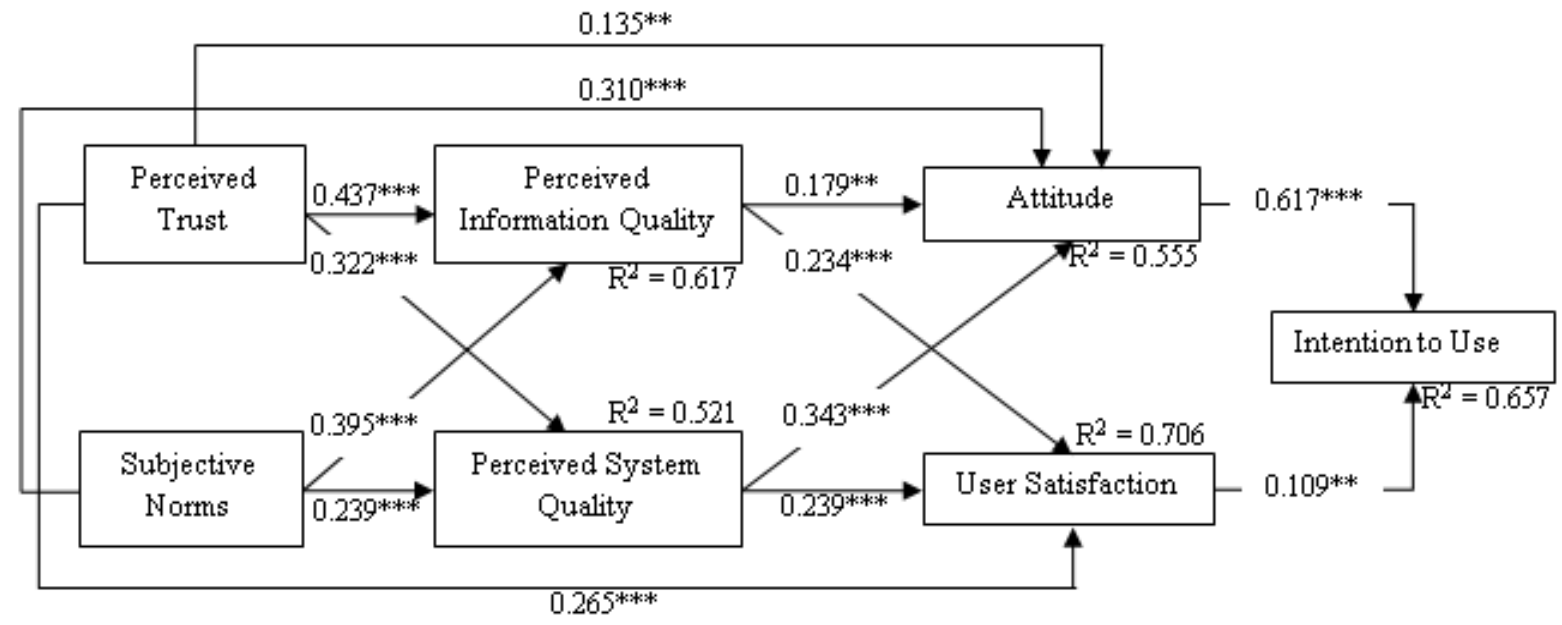

FIG. 2. Regression Analysis of Research Model for the OPGRS Systems

\section{DISCUSSION}

The purpose of the study was to examine the success of the OPGRS systems by developing an e-government IS success model. Therefore, we integrated constructs from the DeLone \& McLean (2003) IS success model and considered some external constructs such as perceived trust, subjective norms, and attitude to design a model suitable for explaining the success of the OPGRS systems. Therefore, the model thus formed, combined a total of seven variables: perceived information quality, perceived system quality, user satisfaction, intention to use, attitude, perceived trust, and subjective norms.

The regression coefficient outcomes also indicated that information and system quality were significant positive determinants of user satisfaction and attitude. Several prior studies on IS success have provided support for the argument that higher levels of information quality lead to increased user satisfaction (Chae \& Kim, 2001; Iavari, 2005; McGill \& Hobbs, 2003; Rai et al., 2002; Seddon, 1997; Seddon \& Kiew, 1996; Teo et al., 2008; Wang \& Liao, 2008; Zhang et al., 2005). For example, using a context of e-government success, Teo et al. (2008) argued that information search was the main purpose of the usage and so the overall 
satisfaction was more influenced by whether the information on the website was accurate and updated for the passive users. We believe that the respondents in our research are although cannot be categorized under either active or the passive users, they would probably show their excitement and curiosity for the information available on the e-government system and would feel more satisfied if the quality of information processing is better in the online system than getting their work done through offline government services.

Similarly, a number of studies (e.g., Chiu et al., 2007; Lee \& Chung, 2009; Negash et al., 2003; Seddon \& Kiew, 1996; Teo et al., 2008) have also shown a support for the significant impact of system quality on user satisfaction. For example, Teo et al. (2008) found that system quality was significantly related to satisfaction for active users but not for passive users. Although our majority of respondents cannot decisively be put in either of the categories explained by Teo et al. (2008), however, we believe that they are such users who are technologically literate and enhanced system quality (such as conciseness, flexibility, ease of use, user friendly interface, and faster response time) does matter a lot for them and their subsequent satisfaction based on their prior experience with similar systems.

However, As far as the relationship between information quality and attitude is concerned, has not been explored in the prior studies on the IS success models. However, Wixdom \& Todd (2005) demonstrated a strong bonding between these two variables with high levels of significance. Selection of attitude as a dependent variable for information as well as system quality was also because of the fact that DeLone \& McLean (2003) suggested that intention to use could be more suitable variable when the system in question is mandatory in nature. As the intent to use the OPGRS systems is completely volitional in nature, it prompted us to use attitude as a surrogate variable for intention to use the system. As a result, both information and system quality were found to positively and significantly predicting the attitude of using the OPGRS systems, though the effect of information quality $(\beta=0.179)$ on attitude is not that strong. Therefore, the government should work on such determinant to enhance its overall effects on the system.

Moreover, similar to the impact of the system and information quality on attitude and user satisfaction, the effects of perceived trust and subjective norms on perceived information quality and perceived system quality was also found significant and even stronger. The positive and significant impact of perceived trust on the perceptions about information and system quality is in accordance with the outcomes obtained from Teo et al. (2008) and Khayun et al. (2012). For example, Teo et al. (2008) argued that trust being the significant predictor of system quality for the passive users. This is because when it comes to information search and downloading, system quality is more likely to be considered as the belief about the arrangement of the websites and the associated information looked for by the users. Therefore, trust on the system would lead the users to form a high perception about the quality of the system. However, active users form the positive perception about the system quality by the more in-depth characteristics (i.e., not merely on the trust) such as evaluation of the design and functionality of the website (Teo et al., 2008). We believe that potential users of the OPGRS systems are not the highly technical people who would look for the more in-depth investigation about the system. Rather, majority of them want to get the complaints 
registered and get the solution on time. Therefore, their trust on the system has led us to the significant impact on both information and system quality.

Similarly, the positive influence of subjective norms on perceived information and system quality is in line with the results shown by Schaupp et al. (2009) in context of online community but was found non-significant for the e-commerce websites. The authors argued that the nature of the online community website was more of public that the users often refer to one another. However, the non-significant nature of the same relationship for e-commerce websites was clarified based more on the user's own purchase experience, rather than being influenced by the important ones (Schaupp et al., 2009). As the OPGRS system is similar to the one defined by Schaupp et al. (2009) as the online community system, it might be believed that the users do influence their referents about the perception of the information and system quality of the system in question.

Moreover, the impact of perceived trust and subjective norms on attitude and perceived trust on user satisfaction were also found positive and significant. Attitude was considered to play the role of mediating variable toward intention to use because of the volitional nature of the OPGRS systems as also suggested by DeLone \& McLean (2003) IS success model. It can also be rationally sensed that perceived trust and social influence from the referent others might persuade individual's belief and positive attitude toward using the system rather intending to use it straight away. In addition, many IS literature in the context of e-commerce (e.g., Balasubramanian et al., 2003; Flavian et al., 2006; Kim et al., 2004; Kim et al., 2009) and a few of them in context of e-government (e.g., Lee \& Chung, 2009; Teo et al., 2008) have advocated the strong association of trust on satisfaction. Teo et al.'s (2008) findings suggested that building trust was necessary for e-government website success. Yoon (2002) also argued that satisfaction could be an outcome of online trust and suggested a constructive correlation between trust and satisfaction.

Taking the case of mobile banking in Korea, Lee \& Chung (2009) revealed that trust significantly affected the degree of satisfaction. We believe that the link of trust and satisfaction happens to be stronger where more sensitive issues such as financial transaction is involved through the e-government websites (as in the case of Lee \& Chung, 2009), however, the significance and relevance of such relationship in the user's other sensitive issues such as the complaint registration and its subsequent response by the government cannot also be avoided. This is why this relationship holds such an important place even in the context of non-transactional e-government services. However, the government should take more initiatives and expedite the complaint hearing and resolving process to build more trust to the citizen's for a larger success perspective of this system.

Finally, the findings also revealed that user satisfaction and attitude toward using the OPGRS systems were the stronger predictors of intention to use it. Consistent with the prior literature on TRA (Ajzen \& Fishbein, 1975), TAM (Davis, 1989), and TPB (Ajzen, 1985; Ajzen, 1991) the relationship between attitude and intention to use the system was supported by many studies (e.g., Karahanna, Straub, \& Chervany, 1999; Hung et al., 2006; Hung et al., 2009; Lin et al., 2011; Susanto \& Goodwin, 2011). For example, in context of Gambian e-government, 
Lin et al. (2011) found the indirect impact of information and system quality on attitude via perceived usefulness and subsequently, attitude was reported to influence the intention to use the system positively and significantly. Moreover, the impact of satisfaction on intention to use has also been supported by many studies on IS satisfaction (e.g., Bhattacherjee, 2001; Hayashi, Chen, Ryan \& Wu, 2004; Chiu et al., 2005; Lin, Wu, Tsai, 2005; McGill \& Hobbs, 2003; Zhang, Fang, Wei, \& Wang, 2012). For example, testing the DeLone and McLean model in the user-developed application domain, McGill \& Hobbs (2003) established that user satisfaction had a significant positive impact on the intended use. This indicates that more satisfied with an application an end user was, the more likely they intended to use the system in the future (McGill \& Hobbs, 2003). Our findings are also in line with the above argument.

The hypothesis testing results indicated that there are strong correlations between the seven constructs. We gained support that there are strong correlations between the seven success constructs, supporting the hypothesized relationships. The similar strong correlations have also been shown by the prior studies (e.g., Floropoulos et al., 2010; Roca, Chiu, \& Martinez, 2006; Teo et al., 2008) on IS success models.

\section{CONCLUSIONS}

This research is a response to a call for the continuous challenge and validation of IS success models in different contexts (DeLone \& McLean, 2003, Rai et al., 2002). The purpose of this study is to examine the success of OPGRS through an e-government based IS success model, which is developed using DeLone and McLean's IS success models. Therefore, we integrated the constructs such as trust, subjective norms, and attitude along the DeLone and McLean (2003) IS success model so that it could explain the success of OPGRS as perceived by the users of the system in context of India.

All the 13 hypotheses performed significantly as per the expectations of the extended IS success models. Therefore, it is quite evident from the empirical findings that the implementation of OPGRS seems to be quite successful even though it is not a very old system. However, it was sensed that the government should take some more initiatives to enhance the information quality of the system to attract more positive responses and enhanced satisfaction levels, which can lead to positive intention to use it. Moreover, the government should take more initiatives toward enhancing perceived trust, positive social influence along with the perceived information and system quality to generate positive attitude to the users of the system. This is because higher satisfaction level and positive attitude toward using the OPGRS systems will define the actual success story of this system in the long run.

\section{LIMITATIONS AND FUTURE RESEARCH DIRECTIONS}

Even though the thorough process has allowed us to develop and validate the e-government based system success model, this study has a number of limitations that can be taken care of in the future research. Firstly, the exploration of IS system success model in context of egovernment system is relatively new to the e-government researchers. Therefore, the caution needs to be taken while generalizing its findings to the other categories of users (i.e. in G2B 
and G2G contexts) as well as applying this model in other developing country even in Government-to-Citizen (G2C) context. Secondly, this model does not measure the concerns of net benefits as defined in the IS success model (DeLone \& McLean, 2003; Seddon, 1997). Hence, measuring net benefits from the citizen's points of view can reveal some more facts about the system. However, future researchers need to clearly and carefully define the stakeholders and situations under which the net benefits are to be examined (DeLone \& McLean, 2003). Thirdly, this study has performed empirical investigation of e-government systems success based on the snapshot view of the sample. The longitudinal view of sample data would allow the researchers to better explore the facts about the actual use of the system and it's after effect. Finally, as the findings of this study cannot be generalized to mandatory settings, further research is required to see the differences of outcomes between voluntary and mandatory settings.

\section{THEORETICAL CONTRIBUTION AND MANAGERIAL IMPLICATIONS}

Firstly, this study is very few among others (e.g., Teo et al., 2008) to extend the online trust literature onto the IS success model in the context of e-government. As the government agencies are providing a large scale of information and services through their websites, it is essential to understand that the investment in building the citizen's trust can lead the system to its success. Secondly, use of the external constructs including perceived trust, subjective norms, and attitude to the DeLone \& McLean's (2003) IS success model provides a better understanding of OPGRS's success. Thirdly, integrated model of any e-government systems success like this is unique in its own and has never been implemented before. The empirical testing outcomes of the hypotheses linked to the model can help the researchers toward gaining further better understanding of users' satisfaction and their attitude toward using the system.

The results obtained by implementing the research model allow the e-government practitioners to realize about the factors to give more attention toward increasing the citizen's satisfaction and enhancing the positive attitude toward using the system in question. The current link of information quality and perceived trust with attitude and user satisfaction with intention to use the system are although significant, it is not strong. The system designer should pay attention toward enhancing the standard of information quality of the system to strengthen user's attitude toward using the system. The practitioners should be given similar recommendations to enhance their image in the eyes of the users to gain more trust to make the users more satisfied with the system.

\section{REFERENCES}

Ajzen, I. (1985). From intentions to actions: A theory of planned behavior. In J. Kuhl, \& J. Beckmann (Eds.), Springer Series in Social Psychology (11-39). Berlin: Springer.

Ajzen, I. (1991). The theory of planned behavior. Organizational Behavior and Human Decision Processes, 50(2), 179-211.

Ajzen, I., \& Fishbein, M. (1972). Attitude and normative beliefs as factors influencing intentions. Journal of Personality and Social Psychology, 21(1), 1-9. 
Ajzen, I., \& Fishbein, M. (1975). Belief, attitude, intention and behavior: An introduction to theory and research. Reading: Addison-Wesley.

Ajzen, I., \& Fishbein, M. (1980). Understanding attitudes and predicting social behavior. Englewood Cliffs, NJ: Prentice-Hall.

Akman, I., Yazici, A., Mishra, A., \& Arifoglu, A. (2005). E-Government: A global view and an empirical evaluation of some attributes of citizens. Government Information Quarterly, 22, 239-257.

Bailey, J.E., \& Pearson, S.W. (1983). Development of a tool for measuring and analyzing computer user satisfaction. Management Science, 29(5), 530-545.

Balasubramanian, S., Konana, P., \& Menon, N.M. (2003). Customer satisfaction in virtual environments: A study of online investing. Management Science, 49(7), 871-889.

Bargas-Avila, J., Brenzikofer, O., Roth, S., Tuch, A., Orsini, S., \& Opwis, K. (2010). Simple but crucial user interfaces in the World Wide Web: Introducing 20 guidelines for usable web form design. In: Matrai, R. (Ed.), User Interfaces. INTECH, 1-10.

Benton, A., Gelber, E.H., Kelley, H., \& Liebling, B. (1969). Reactions to various degrees of deceit in a mixed-motive relationship. Journal of Personality and Social Psychology, 12(2), 170-180.

Bhattacherjee, A. (2001). Understanding information systems continuance: An expectationconfirmation model. MIS Quarterly, 25(3), 351-370.

Chae, M., \& Kim, J. (2001). Information quality for mobile internet services: A theoretical model with empirical validation. In Proceedings of the Twenty-second International Conference on Information Systems New Orleans, LA, USA, 43-54.

Chai, S., Herath, T.C., Park, I., \& Rao, H.R. (2006). Repeated Use of E-Gov Web Sites: A Satisfaction and Confidentiality Perspective. International Journal of Electronic Government Research, 2(3), 1-22.

Chakravarty, S., Feinberg, R., \& Widdows, R. (1997). Reasons of their discontent. Bank Marketing, 29(11), 49-52.

Chen, C-W. (2010). Impact of quality antecedents on taxpayer satisfaction with online taxfiling systems - An empirical study. Information \& Management, 47(5), 308-315.

Chen, Q. (1999). Attitude toward the Site. Journal of Advertising Research, 39(5), 27-37.

Chiu, C.M., Chiu, C.S., \& Chang, H.C. (2007). Examining the integrated influence of fairness and quality on learners' satisfaction and Web-based learning continuance intention. Information Systems Journal, 17(3), 271-287.

Chiu, C.M., Hsu, M.H., Sun, S.Y., Lin, T.C., \& Sun, P.C. (2005). Usability, quality, value and e-learning continuance decisions. Computers and Education, 45(4), 399-416.

Choudrie, J., \& Dwivedi, Y.K. (2005). Investigating the research approaches for examining technology adoption issues. Journal of Research Practice, 1(1), Article D1. 
Chu, P.Y., Hsiao, N., Lee, F.W., \& Chen, C.W. (2004). Exploring Success factors for Taiwan's government electronic tendering system: Behavioral perspectives from end users. Government Information Quarterly, 21(2), 219-234.

Conrath, D., \& Mignen, O. (1990). What is being done to measure user satisfaction with EDP/MIS. Information \& Management, 19(1), 7-19.

Cornford, T., \& Smithson, S. (1996). Project Research in Information Systems: A Student's Guide, London: Macmillan Press Ltd.

Davis, F.D. (1989). Perceived usefulness, perceived ease of use, and user acceptance of information technology. MIS Quarterly, 13(3), 318-346.

Davis, F.D., Bagozzi, R.P., \& Warshaw, P.R. (1989). User Acceptance of Computer Technology: A comparison of Two Theoretical Models. Management Science, 35(8), 9821003 .

DeLone, W.H., \& McLean, E.R. (1992). Information systems success: The quest for the dependent variable. Information Systems Research, 3(1), 60-95.

DeLone, W.H., \& McLean, E.R. (2003). The DeLone and McLean Model of information systems success: A ten year update. Journal of Management Information Systems, 19(4), 930 .

Delone, W.H., \& Mclean, E.R. (2004). Measuring e-commerce success: Applying the DeLone \& McLean information systems success model. International Journal of Electronic Commerce, 9(1), 31-47.

Doll, W.J., \& Torkzadeh, G. (1988). The measurement of end-user computing satisfaction. MIS Quarterly, 12(2), 259-274.

Dwivedi, Y.K., Weerakkody, V., \& Janssen, M. (2012). Moving towards maturity: Challenges to successful e-government implementation and diffusion. ACM SIGMIS Database, 42(4), 11-22.

Etezadi-Amoli, J., \& Farhoomad, A.F. (1996). A structural model of end user computing satisfaction and user performance. Information \& Management, 30(2), 65-73.

Fishbein, M., \& Ajzen, I. (1975). Belief, Attitude, Intention and Behavior: An Introduction to Theory and Research. Reading, MA: Addison-Wesley Publishing Company.

Fishbein, M., \& Ajzen, I. (1980). Understanding attitudes and predicting social behavior. Prendice Hall. New York.

Flavian, C., Guinaliu, M., \& Gurrea, R. (2006). The role played by perceived usability, satisfaction, and consumer trust on website loyalty. Information \& Management, 43(1), 1-14.

Floropoulos, J., Spathis, C., Halvatzis, D., \& Tsipouridou, M. (2010). Measuring the success of the Greek Taxation Information System. International Journal of Information Management, 30(1), 47-56.

Fowler, F.J. (2002). Survey Research Methods, London: SAGE Publications Inc. 
Gefen, D., Benbasat, I., \& Pavlou, P.A. (2008). A Research Agenda for Trust in Online Environments. Journal of Management Information Systems, 24(4), 275-286.

Gefen, D., Karahanna, E., \& Straub, D.W. (2003). Trust and TAM in online shopping: An integrated model. MIS Quarterly, 27(1), 51-90.

Gelderman, M. (1998). The relation between user satisfaction, usage of information systems, and performance. Information \& Management, 34(1), 11-18.

Gotoh, R. (2009). Critical factors increasing user satisfaction with e-government services. Electronic Government, an International Journal, 6(3), 252-264.

Grewal, R., Comer, J.M., \& Mehta, R. (1999). Does trust determine satisfaction in marketing channel relationships? The moderating role of exchange partner's price competitiveness. Journal of Business-to-Business Marketing, 6(1), 1-18.

Guimaraes, T., \& Igbaria, M. (1997). Client/server system success: Exploring the human side. Decision Sciences, 28(4), 851-875.

Gupta, M.P., \& Jana, D. (2003). EGovernment evaluation: A framework and case study. Government Information Quarterly, 20(4), 365-387.

Hair, J.F., \& Anderson, R.E., Tatham, R.L., \& Black, W.C. (1992). Multivariate data analysis, with readings (3rd Ed.). New York, NY: Macmillan Publishing Company.

Hayashi, A., Chen, C., Ryan, T., \& Wu, J. (2004). The role of social presence and moderating role of computer self-efficacy in predicting the continuance usage of e-learning systems. Journal of Information Systems Education, 15(2), 139-154.

Heeks, R. (2006). Implementing and managing e-Government: An international text. London: Sage.

Hinton, P. R., Brownlow, C., McMurray, I., \& Cozens, B. (2004). SPSS explained. East Sussex, England: Routledge Inc.

Hsu, F-M., \& Chen, T-Y. (2007). Understanding Information Systems Usage Behavior in EGovernment: The Role of Context and Perceived Value. Pacific Asia Conference on Information Systems, 477-490.

Hu, P.J-H., Brown, S.A., Thong, J.Y.L, Chan, F.K.Y., \& Tam, K.Y. (2009). Determinants of Service Quality and Continuance Intention of Online Services: The Case of eTax. Journal of the American Society for Information Science and Technology, 60(2), 292-306.

Hung, S-Y., Chang, C-M., \& Yu, T-J. (2006). Determinants of user acceptance of the Government services: The case of online tax filing and payment system. Government Information Quarterly, 23(1), 97-122.

Hung, S-Y., Tang, K-Z., Chang, C-M., \& Ke, C-D. (2009). User acceptance of intergovernmental services: An example of electronic document management system. Government Information Quarterly, 26(2), 387-397. 
Hussein, R., Karim, N.S.A., \& Selamat, M.H. (2007). The impact of technological factors on information systems success in the electronic-government context. Business Process Management Journal, 13(5), 613-627.

Iavari, J. (2005). An empirical test of the DeLone - McLean model of information system success. The Data Base for Advances in Information Systems, 36(2), 8-27.

Ives, B., \& Olson, M. (1984). User involvement and MIS success: A review of research. Management Science, 30(5), 586-603.

Ives, B., Olson, M.H., \& Baroudi, J. (1983). Measurement of user information satisfaction. Communications of the ACM, 26(10), 785-793.

Jaeger, P.T. (2003). The endless wire: E-Government as global phenomenon. Government Information Quarterly, 20(4), 323-331.

Janssen, D., Rotthier, S., \& Snijkers, K. (2004). If you measure it they will score: An assessment of international eGovernment benchmarking. Information Polity, 9(3), 121-130.

Karahanna, E., Straub, D.W., \& Chervany, N.L. (1999). Information technology adoption across time: A cross-sectional comparison of pre-adoption and post-adoption beliefs. MIS Quarterly, 23(2), 182-213.

Kelman, H.C. (1958). Compliance, identification, and internalization: three processes of attitude change. Journal of Conflict Resolution, 2(1), 51-60.

Kelman, H.C. (1974). Further Thoughts on the Processes of Compliance, Identification, and Internalization. Aldine, Chicago.

Khayun, V., Ractham, P., \& Firpo, D. (2012). Assessing e-EXCISE success with DeLone and McLean'S model. Journal of Computer Information Systems, 52(3), 31-40.

Kim, D.J., Ferrin, D.L., \& Rao, H.R. (2009). Trust and satisfaction, two stepping stones for successful e-commerce relationships: A longitudinal exploration. Information Systems Research, 20(2), 237-257.

Kim, M., Park, M., Jeong, D. (2004). The effects of customer satisfaction and switching barrier on customer loyalty in Korean mobile telecommunication services. Telecommunications Policy, 28(2), 145-159.

Lee, K.C., \& Chung, N. (2009). Understanding factors affecting trust in and satisfaction with mobile banking in Korea: A modified DeLone and McLean's model perspective. Interacting with Computers, 21(5), 385-392.

Li, X., Hess, T.J., \& Valacich, J.S. (2006). Using attitude and social influence to develop an extended trust model for information systems. Database for Advances in Information Systems, 37(2-3), 108-124.

Li, X., Hess, T.J., \& Valacich, J.S. (2008). Why do we trust new technology? A study of initial trust formation with organizational information systems. The Journal of Strategic Information Systems, 17(1), 39-71. 
Lin, C.S., Wu, S., \& Tsai, R.J. (2005). Integrating perceived playfulness into expectationconfirmation model for web portal context. Information \& Management, 42(5), 683-693.

Lin, F., Fofanah, S.S., \& Liang, D. (2011). Assessing citizen adoption of e-Government initiatives in Gambia: A validation of the technology acceptance model in information systems success. Government Information Quarterly, 28(2), 271-279.

Lind, E.A., Tyler, T.R., \& Huo, Y. (1997). Procedural context and culture: Variation in the antecedents of procedural justice judgments. Journal of Personality and Social Psychology, 73(4), 767-780.

Lu, C-T., Huang, S-Y., \& Lo, P-Y. (2010). An empirical study of on-line tax filing acceptance model: Integrating TAM and TPB. African Journal of Business Management, $4(5), 800-810$.

Maes, A., \& Poels, G. (2007). Evaluating quality of conceptual modelling scripts based on user perceptions. Data and Knowledge Engineering, 63(3), 701-724.

Mathieson, K. (1991). Predicting User Intentions: Comparing the Technology Acceptance Model with the Theory of Planned Behavior. Information Systems Research, 2(3), 173-191.

McGill, T., \& Hobbs, V. (2003). User-developed applications and information systems success: A test of DeLone and McLean's model. Information Resources Management Journal, 16(1), 24-45.

McGorry, S.Y. (2003). Measuring quality in online learning programs. Internet and Higher Education, 6(2), 159-177.

McKinney, V., Yoon, K., \& Zahedi, F. (2002). The measurement of Web-Customer satisfaction: An expectation and disconfirmation approach. Information Systems Research, 13(3), 296-315.

McKnight, D.H., Choudhury, V., \& Kacmar, C. (2000). Trust in e-commerce vendors: A two-stage model. In Proceedings of the $21^{\text {st }}$ International Conference on Information Systems, Brisbane, Queensland, Australia.

Melone, N. (1990). A theoretical assessment of the user-satisfaction construct in information systems research. Management Science, 36(1), 76-91.

Myers, B.L., Kappelman, L.A., \& Prybutok, V.R.A. (1997). Comprehensive model for assessing the quality and productivity of the information systems function: Toward a contingency theory for information systems assessment. Information Resources Management Journal, 10(1), 6-25.

Negash, S., Ryan, T., \& Igbaria, M. (2003). Quality and effectiveness in Web-based customer support systems. Information \& Management, 40(8), 757-768.

Nunnaly, J. (1978). Psychometric theory. New York: McGraw-Hill.

Palmer, J.W. (2002). Web site usability, design, and performance metrics. Information Systems Research, 13(2), 151-167. 
Patterson, P., Johnson, L., \& Spreng, R. (1997). Modeling the determinants of customer satisfaction for business to business professional services. Journal of the Academy of Marketing Science, 25(1), 4-17.

Pavlou, P.A. (2003). Consumer acceptance of electronic commerce: Integrating trust and risk with the technology acceptance model. International Journal of Electronic Commerce, 7(3), 101-134.

Pavlou, P.A., \& Fygenson, M. (2006). Understanding and predicting electronic commerce adoption: an extension of the theory of planned behavior. MIS Quarterly, 30(1), 115-143.

Petter, S., \& McLean, E. R. (2009). A meta-analytic assessment of the DeLone and McLean IS success model: An examination of IS success at the individual level. Information \& Management, 46(3), 159-166.

Petter, S., DeLone, W., \& McLean, E. (2008). Measuring information systems success: models, dimensions, measures, and interrelationships. European Journal of Information Systems, 17(3), 236-263.

Pitt, L.F., Watson, R.T., \& Kavan, C.B. (1995). Service quality: A measure of information systems effectiveness. MIS Quarterly, 19(2), 173-188.

Rai, A., Lang, S.S., \& Welker, R.B. (2002). Assessing the validity of IS success models: An empirical test and theoretical analysis. Information Systems Research, 13(1), 50-69.

Rana, N.P., Dwivedi, Y.K. and Williams, M.D. (2013a). E-government adoption research: An analysis of the employee's perspective. International Journal of Business Information Systems, 14(4), 414-428.

Rana, N.P., Dwivedi, Y.K. and Williams, M.D. (2013b). Examining the factors affecting intention to use of, and user satisfaction with online public grievance redressal system (OPGRS) in India. In Dwivedi, Y.K., Zinner Henriksen, H., Wastell, D. and De', R. (Eds.): Proceedings of IFIP WG 8.6 International Conference on Transfer and Diffusion of IT, TDIT 2013, Bangalore, India, Grand Successes and Failures in IT: Public and Private Sectors, Springer, Berlin, Heidelberg, 27-29 June, 240-260.

Rana, N.P., Dwivedi, Y.K. and Williams, M.D. (2013c). Evaluating the validity of IS success models for the electronic government research: An empirical test and integrated model. International Journal of Electronic Government Research, 9(3), pp.1-22.

Rana, N.P., Dwivedi, Y.K. and Williams, M.D. (2013d). A meta-analysis application for synthesizing findings of existing research on citizen adoption of e-government. Information Systems Frontiers, DOI: 10.1007/s10796-013-9431-z.

Rana, N.P., Dwivedi, Y.K. and Williams, M.D. (2014). A review and weight analysis of the predictors and linkages in electronic government adoption research. International Journal of Indian Culture and Business Management, 8(2), 139-158.

Ratnasingham, P. (1998a). The importance of trust in electronic commerce. Internet Research, 8(4), 313-321. 
Ratnasingham, P. (1998b). Trust in web-based electronic commerce security. Information Management \& Computer Security, 6(4), 162-166.

Reddick, C.G. (2005). Citizen interaction with e-government: from the streets to servers? Government Information Quarterly, 22(1), 38-57.

Roberts, K., \& O'Reilly, C. (1974). Failures in upward communication in organizations: Three possible culprits. Academy of Management Journal, 17(2), 205-215.

Roca, J.C., Chiu, C.M., \& Martinez, F.J. (2006). Understanding e-learning continuance intention: An extension of the Technology Acceptance Model. International Journal of Human-Computer Studies, 64(8), 683-696.

Rousseau, D., \& Tijoriwala, S. (1999). What's a good reason to change? Motivated reasoning and social accounts in promoting organizational change. Journal of Applied Psychology, 84(4), 514-528.

Sahu, G.P., \& Gupta, M.P. (2007). Users' Acceptance of E-Government: A study of Indian central Excise. International Journal of Electronic Government Research, 3(3), 1-21.

Sambasivan, M., Wemyss, G.P., \& Rose, R.C. (2010). User acceptance of a G2B system: A case of electronic procurement system in Malaysia. Internet Research, 20(2), 169-187.

Schaper, L.K., \& Pervan, G.P. (2007). ICT and OTs: A model of information and communication technology acceptance and utilisation by occupational therapists. International Journal of Medical Informatics, 76(1), S212-S221.

Schaupp, L.C., Belanger, F., \& Fan, W. (2009). Examining the success of websites beyond ecommerce: An extension of the IS success model. Journal of Computer Information Systems, 49(4), 42-52.

Scott, M., \& DeLone, W.H. (2009). Understanding Net Benefits: A Citizen-Based Perspective on E-government Success. International Conference on Information Systems, 111.

Seddon P.B., Staples, S., Patnayakuni, R., \& Bowtell, M. (1999). Dimensions of information systems success. Communications of the Association for Information Systems, 2(20), 2-39.

Seddon, P.B. (1997). A respecification and extension of the DeLone and McLean model of IS success. Information Systems Research, 8(3), 240-253.

Seddon, P.B., \& Kiew, M.-Y. (1994). A partial test and development of the DeLone and McLean model of IS success. In J.I. DeGross, S.L. Huff, and M.C. Munro (eds.), Proceedings of the International Conference on Information Systems. Atlanta, GA: Association for Information Systems, 99-110.

Seddon, P.B., \& Kiew, M.Y. (1996). A partial test and development of DeLone and McLean's model of IS success. Australian Journal of Information Systems, 4(1), 90-109.

Seddon, P.B., Staples, D.S., Patnayakuni, R., \& Bowtell, M.J. (1999). The dimensions of information systems success. Communications of the Association for Information Systems, 2(20), 1-39. 
Shannon, C.E., \& Weaver, W. (1949). The mathematical theory of communication. Urbana, IL: University of Illinois Press.

Shareef, M.A., Kumar, V., Kumar, U., \& Dwivedi, Y.K. (2011). E-Government Adoption Model (GAM): Differing service maturity levels. Government Information Quarterly, 28, 1735 .

Sharifi, H., \& Zarei, B. (2004). An adaptive approach for implementing e-government in I.R. Iran. Journal of Government Information, 30(5), 600-619.

Shin, D. (2009). An empirical investigation of a modified technology acceptance model of IPTV. Behaviour and Information Technology, 28(4), 361-72.

Shin, D-H. (2007). User acceptance of mobile Internet: Implication for convergence technologies. Interacting with Computers, 19(4), 472-483.

Sitkin, S.B., \& Roth, N.L. (1993). Exploring the limited effectiveness of legalistic "remedies for trust/distrust”. Organization Science, 4(3), 367-392.

Susanto, T.D., \& Goodwin, R. (2011). User Acceptance of SMS-Based eGovernment Services. In M. Janssen, H.J. Scholl, M.A. Wimmer, and Y-H. Tan (Eds.): EGOV 2011, LNCS 6846, 75-87.

Szajna, B. (1996). Empirical Evaluation of the Revised Technology Acceptance Model. Management Science, 42(1), 85-92.

Teng, J., \& Calhoun, K. (1996). Organizational computing as a facilitator of operational and managerial decision making: An exploratory study of managers' perceptions. Decision Sciences, 27(4), 673-710.

Teo, T.S., Srivastava, S.C., \& Jiang, L. (2008). Trust and electronic government success: An empirical study. Journal of Management Information Systems, 25(3), 99-132.

Venkatesh, V., \& Davis, F.D. (2000). A theoretical extension of the technology acceptance model: Four longitudinal field studies. Management Science, 46(2), 186-204.

Venkatesh, V., Morris, M., Davis, G., \& Davis, F. (2003). User acceptance of information technology: Toward a unified view. MIS Quarterly, 27(3), 425-478.

Wang, T., Cao, Y., \& Yang, S. (2010). Building the Model of Sustainable Trust in Egovernment. $2^{\text {nd }}$ IEEE International Conference on Information and Financial Engineering, 698-701.

Wang, Y-S., \& Liao, Y-W. (2008). Assessing eGovernment systems success: A validation of the DeLone and McLean model of information systems success. Government Information Quarterly, 25(4), 717-733.

Wangpipatwong, S., Chutimaskul, W., \& Papasratorn, B. (2009). Quality Enhancing the Continued Use of E-Government Web Sites: Evidence from E-Citizens of Thailand. International Journal of Electronic Government Research, 5(1), 19-35.

Warkentin, M., Gefen, D., Pavlou, P.A., \& Rose, G.M. (2002). Encouraging citizen adoption of e-government by building trust. Electronic Markets, 12(3), 157-162. 
Wixom, B.H., \& Todd, P.A. (2005). A theoretical integration of user satisfaction and technology acceptance. Information Systems Research, 16(1), 85-102.

Wixom, B.H., \& Watson, H.J. (2001). An empirical investigation of the factors affecting data warehousing success, MIS Quarterly, 25(1), 17-41.

Yoon, S.J. (2002). The antecedents and consequences of trust in online purchase decision. Journal of Interactive Marketing, 16(2), 47-63.

Yusuf, Y., Gunasekaran, A., \& Abthorpe, M.K. (2004). Enterprise information systems project implementation: A case study of ERP in Rolls-Royce. International Journal of Production Economics, 87(3), 251-266.

Zhang, Y., Fang, Y., Wei, K-K., \& Wang, Z. (2012). Promoting the intention of students to continue their participation in e-learning systems, Information Technology \& People, 25(4), 356-375.

Zhang, Z., Leeb, M.K.O., Huanga, P., Zhang, L., \& Huang, X. (2005). A framework of ERP systems implementation success in China: An empirical study. International Journal of Production Economics, 98(1), 56-80.

Zikmund, G.W. (1994). Business research methods, (4th Edition). New York, NY: The Dryden Press. 